IZA DP No. 7319

Just the Facts, Ma'am: Postsecondary Education and Labor Market Outcomes in the U.S.

Harry J. Holzer

Erin Dunlop

March 2013 


\title{
Just the Facts, Ma'am: Postsecondary Education and Labor Market Outcomes in the U.S.
}

\author{
Harry J. Holzer \\ Georgetown University, \\ AIR and IZA \\ Erin Dunlop \\ AIR \\ Discussion Paper No. 7319 \\ March 2013 \\ IZA \\ P.O. Box 7240 \\ 53072 Bonn \\ Germany \\ Phone: +49-228-3894-0 \\ Fax: +49-228-3894-180 \\ E-mail: iza@iza.org
}

\begin{abstract}
Any opinions expressed here are those of the author(s) and not those of IZA. Research published in this series may include views on policy, but the institute itself takes no institutional policy positions. The IZA research network is committed to the IZA Guiding Principles of Research Integrity.

The Institute for the Study of Labor (IZA) in Bonn is a local and virtual international research center and a place of communication between science, politics and business. IZA is an independent nonprofit organization supported by Deutsche Post Foundation. The center is associated with the University of Bonn and offers a stimulating research environment through its international network, workshops and conferences, data service, project support, research visits and doctoral program. IZA engages in (i) original and internationally competitive research in all fields of labor economics, (ii) development of policy concepts, and (iii) dissemination of research results and concepts to the interested public.
\end{abstract}

IZA Discussion Papers often represent preliminary work and are circulated to encourage discussion. Citation of such a paper should account for its provisional character. A revised version may be available directly from the author. 


\section{ABSTRACT \\ Just the Facts, Ma'am: Postsecondary Education and Labor Market Outcomes in the U.S.*}

In this paper, we provide a comprehensive and up-to-date snapshot of the most important postsecondary education and labor market outcomes in the U.S. using two nationally representative sources of data: The Survey of Income and Program Participation (SIPP) and The National Educational Longitudinal Survey (NELS). We find that postsecondary educational attainment has risen modestly among young Americans over the past two decades, with greater gains in BA attainment in the 1990s and in certificate and AA attainment since 2000 (though attainment rose during the Great Recession at all levels). Both younger and older cohorts of blacks and Hispanics have made relative progress in the attainment of certificates and AAs but still lag behind whites in the entry into and completion of BA programs; completion rates in BA programs also lag substantially for those from lowincome families or with weak academic achievement in high school. Young women (especially among whites and blacks) now achieve sub-BA and BA degrees at higher levels than their male counterparts and generally have higher achievement. There are labor market returns for all postsecondary credentials, including certificates and AA degrees, though these vary across field of study. Large gender gaps exist in field of study, with men more concentrated in high-paying fields. Lastly, we find that high school achievement measures can account for much of the racial gaps in BA completion and earnings and some of the gaps by family background, though they account for little of the continuing gender gap favoring young men in earnings.

JEL Classification: $\quad$ 123, I24, J24

Keywords: postsecondary education, earnings, labor market

Corresponding author:

Harry J. Holzer

Georgetown Public Policy Institute

401 Old North, Georgetown Univ.

37 and $O$ St. NW

Washington, DC 20007

USA

E-mail: hjh4@georgetown.edu

\footnotetext{
* We thank Vicky Brady, Alvaro Ballarin Cabrera, Matt Corritore and Annie Downs for excellent research assistance.
} 


\section{Introduction}

Interest in postsecondary educational attainment among disadvantaged populations, and how education helps determine labor market outcomes, remains very strong in the U.S. Despite voluminous literatures on both topics, much remains to be learned about policies that might improve both sets of outcomes. Some major new research efforts, which mostly use newly available sources of administrative data at the state level, are now underway to further explore these issues. ${ }^{1}$

But what are the basic facts on postsecondary education and labor market outcomes, especially regarding gaps between the disadvantaged and other students, which could provide a starting point for this new research? What appears to be true at the national level - in terms of trends over time, gaps across different groups, and the like - that can then be further explored at the state level with other sources of data? What facts do we know about trends in and rewards to sub-BA credentials - like labor market certificates and AA degrees - as well as degrees at the BA level and above?

In this paper, we seek to provide a fairly comprehensive and up-to-date snapshot of the most important postsecondary education and labor market outcomes in the U.S. We review mostly summary evidence on postsecondary and labor market outcomes using two nationally representative sources of data: 1) The Survey of Income and Program Participation (SIPP); and 2) The National Educational Longitudinal Survey (NELS). Both sources contain extensive micro data on individual demographics; educational attainment, including occupational certificates; field of study on certificates and AA degrees, as well as on BA degrees and higher; and on labor market outcomes.

Each data source has both strengths and weaknesses. The SIPP data are based on a representative sample of Americans of all ages, and the survey was administered at different points of time. It is thus useful for studying trends over time in postsecondary attainment and in employment outcomes of all groups. In contrast, the NELS data focus on a single cohort of youth: those who were in grade 8 in 1988. While it lacks the broader cross-sectional coverage and variation over time of the SIPP data, the NELS data are much richer on individual academic experiences and achievement during high school, including courses taken and grades received, as well as aptitude test scores. The NELS also contains information on family background, and provides separate information on attendance without completion at 2-year versus 4-year schools.

Below we review the findings of the tables of summary outcomes that we have produced with each data source. First we review the findings of the SIPP data. We have tabulated comparable results for those aged 25-69 and also those aged 25-29 in various years. We focus on the younger

\footnotetext{
${ }^{1}$ These efforts include research done at the new Center for the Analysis of Postsecondary Employment and Earnings (CAPSEE) at Columbia University as well as at the Center for the Analysis of Longitudinal Data in Education Research (CALDER) at the American Institutes for Research.
} 
cohort in the text, because their outcomes more accurately reflect trends in educational attainment at different points in time; and also because our analysis of NELS and state-level data will focus on youth and young adults as well. But identical results to the tables in the text for the younger cohort appear for all age groups in the Appendix. We present SIPP data from 1990, 2001 and 2007 to infer secular trends in educational attainment for both age groups, while we also compare results from 2007 and 2010 to infer cyclical changes in enrollments and employment outcomes. We then review the NELS data for 2000, during which respondents were roughly 26 years of age, which generates comparable results to the SIPP data for young adults in 2001.

After presenting the basic facts, we briefly review their consistency with the enormous existing body of research literature, and then conclude with a summary of what we have learned and what remains to be explored.

\section{Empirical Results}

\section{A. SIPP Data}

\section{College Attainment and Fields of Study}

We begin by reviewing summary data on postsecondary educational and labor market outcomes tabulated from the SIPP data. Figure 1 presents data on educational attainment in four years: 1990, 2001, 2007 and 2010. These first three dates roughly correspond to the last three business cycle peaks, while the fourth represents the trough of the Great Recession. We present the percentages of the population with high school or less, some college but no degree, the attainment of certificates or AA degrees at the 2-year level, and the attainment of BA degrees or higher. 
Figure 1: Educational Attainment by Year, Ages 25-29

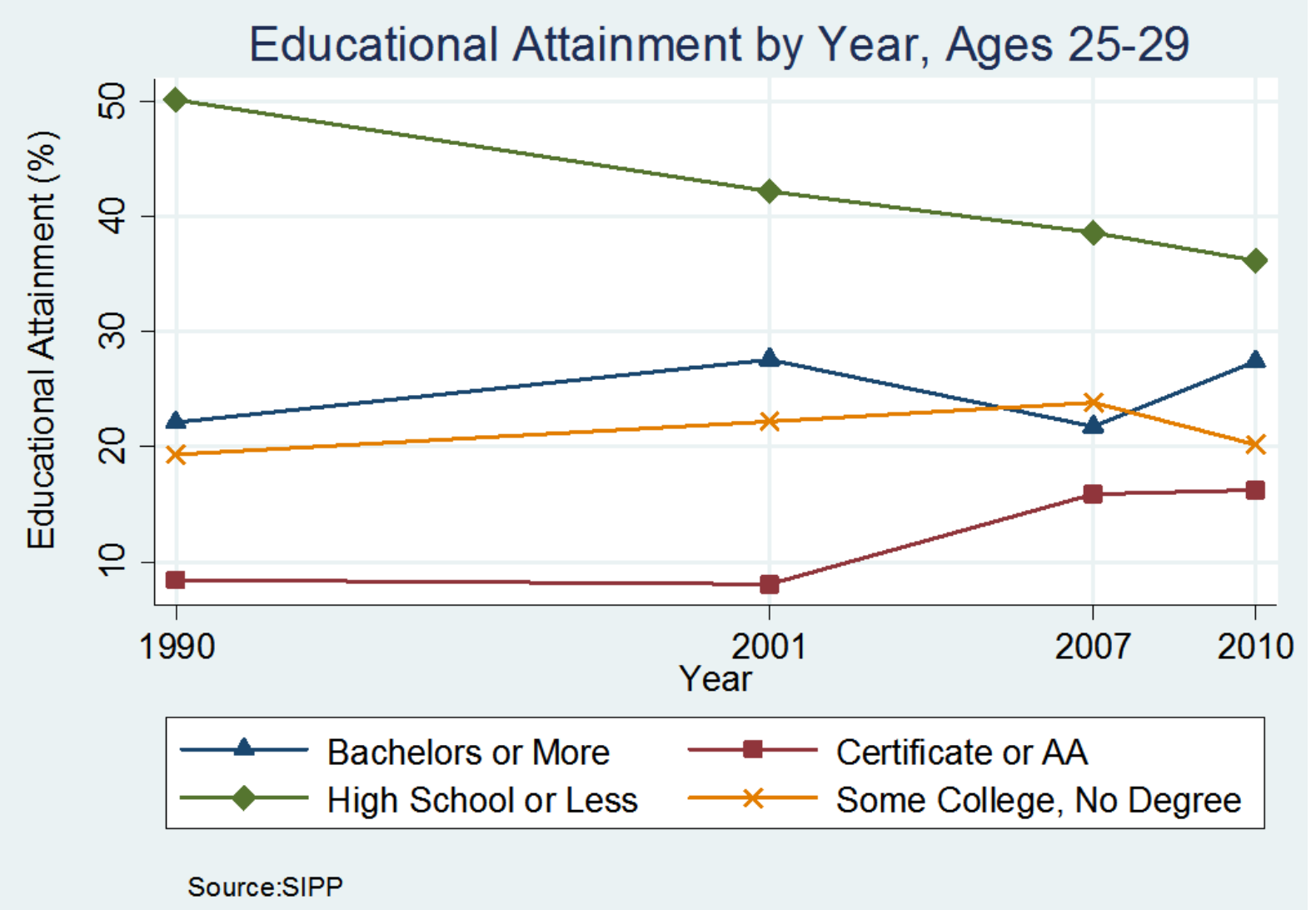

The underlying data for more disaggregated levels of schooling attainment appear in Tables 1(A) for those aged 25-29 and Appendix Table A1(A) for all age groups. Whether certificates are limited only to those for academic credit is somewhat ambiguous from the wording in the SIPP survey. ${ }^{2}$ Also, those obtaining GEDs are lumped together with high school graduates in 1990 but appear separately in all other years.

\footnotetext{
${ }^{2}$ The 1990 question in the SIPP asks, "What is the highest degree beyond a high school diploma that has been earned?" Among those who say they have attended at least one year of college, a "vocational certificate or diploma" is listed as an option. For 2000 and beyond, the question asks about "the highest degree received" and lists "diploma or certificate from a vocational, technical trade or business school beyond high school" as an option. The change in wording in the 1990s might lead to some upward bias in estimates of the growth of certificate attainment (since the years after 2000 do not condition the attainment of a certificate on a year of college attendance). The NELS question, referring back to an answer given in the1994 panel, follows up by asking "What other types of degrees or certificates (if any) did you receive?" from a university, college or trade school. There is a second question about occupational licensing that seems designed to separately pick up nonacademic (or not-for-credit) credentials but that question is listed after the one on degrees and certificates.
} 


\begin{tabular}{|l|c|c|c|c|}
\hline \multicolumn{5}{|c|}{ Table 1(A) - Educational Attainment - Ages 25-29 } \\
\hline \hline Degree & 1990 & 2001 & 2007 & 2010 \\
\hline Dropout & .13 & .13 & .13 & .11 \\
GED & - & .06 & .06 & .05 \\
High School Graduate & .37 & .23 & .20 & .20 \\
Some College & .20 & .22 & .23 & .21 \\
Certificate & .03 & .04 & .07 & .07 \\
Associates & .06 & .04 & .09 & .09 \\
Bachelors & .18 & .22 & .20 & .22 \\
Masters & .03 & .05 & .02 & .04 \\
Professional & .01 & .01 & .01 & .01 \\
Doctorate & .00 & .00 & .00 & .00 \\
\hline Sample N & 16453 & 15201 & 6093 & 13385 \\
\hline
\end{tabular}

Note: (1) The information presented in this table is based on sample-weighted data. (2) Subjects were excluded from the sample if their age was below 25 or above 69 , their hourly income was below $\$ 3$ or above $\$ 100$, were only on either the core file or topical module but not on both, or were not interviewed in the reference month. (3) Due to survey design constraints, GED holders are categorized as HS Grads in the 1990 data; whereas in the 2000s tables they are categorized separately.

The results in Figure 1 and Tables 1(A) and A1(A) show generally rising educational attainment over the past two decades, though somewhat unevenly over time and across degrees. The percentages of individuals with high school or less education drop consistently over time. ${ }^{3}$ The percentage with a BA degree rises during the 1990s for both age groups but much less after 2001. In contrast, the fractions of individuals with sub-BA postsecondary attainments - including both certificates and AA degrees - rise considerably after 2000. This result also appears in the Integrated Postsecondary Educational Data Systems (IPEDS) data for this time period. ${ }^{4}$

We also find some evidence of rising educational attainment during the Great Recession. Over the three-year period 2007-2010, we find rising attainment of BA degrees and above among all ages and especially among the young cohort, with certificate attainment also rising for the former group.

The results are presented separately by race and gender in Figure 2 for 2010 and in Tables 1(B) and A1(B) over the 20 year period. Within racial groups, we see postsecondary attainment generally rising more rapidly for females than males since 1990 in the tables, especially at the BA level. Indeed, a "gender gap" favoring women in the attainment of BA and higher degrees has clearly emerged by 2010 for whites and blacks among the younger cohort, which can be seen clearly in Figure 2.

\footnotetext{
${ }^{3}$ The percentage of Americans without a high school diploma drops considerably among the total population but very little among those aged 25-29, implying that the former result might be driven by the aging out of the sample of older cohorts with high rates of high school non-completion.

${ }^{4}$ The growth in certificates (which include only those for academic credit) in the IPEDS can be measured from tables on "Awards conferred by Title IV degree-granting institutions, by race/ethnicity, level of award and gender: for the United States" at the IPEDS website: http://nces.ed.gov/datalab/tableslibrary/searchresults.aspx?type=search\&keywords=2005156.
} 
Figure 2: Educational Attainment by Race/Gender, 2010

Educational Attainment By Race/Gender, Ages 25-29, 2010 $\mathrm{BA}$ and Above

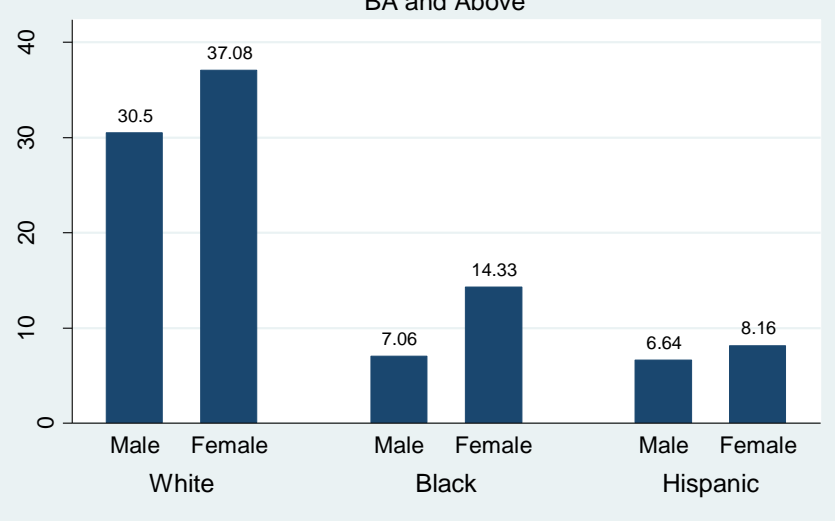

Source:SIPP

Educational Attainment By Race/Gender, Ages 25-29, 2010

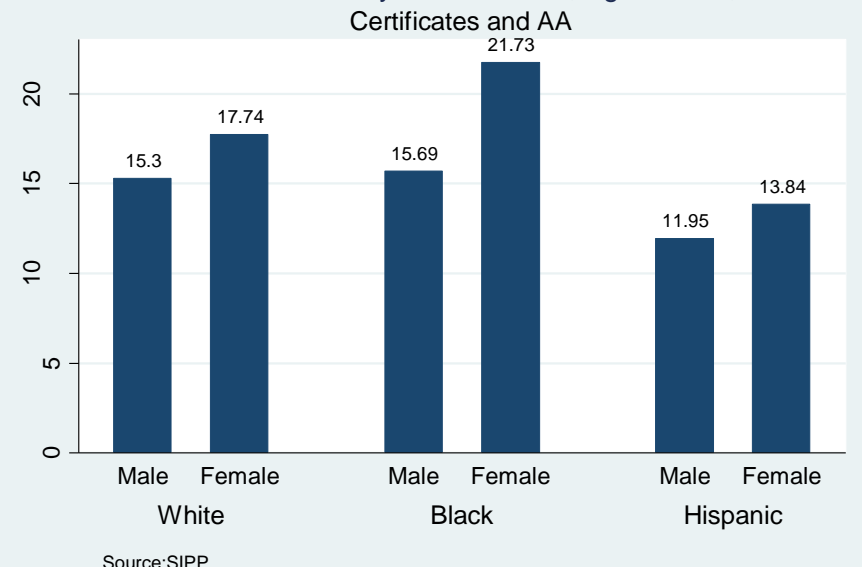

Source:SIPP

Educational Attainment By Race/Gender, Ages 25-29, 2010

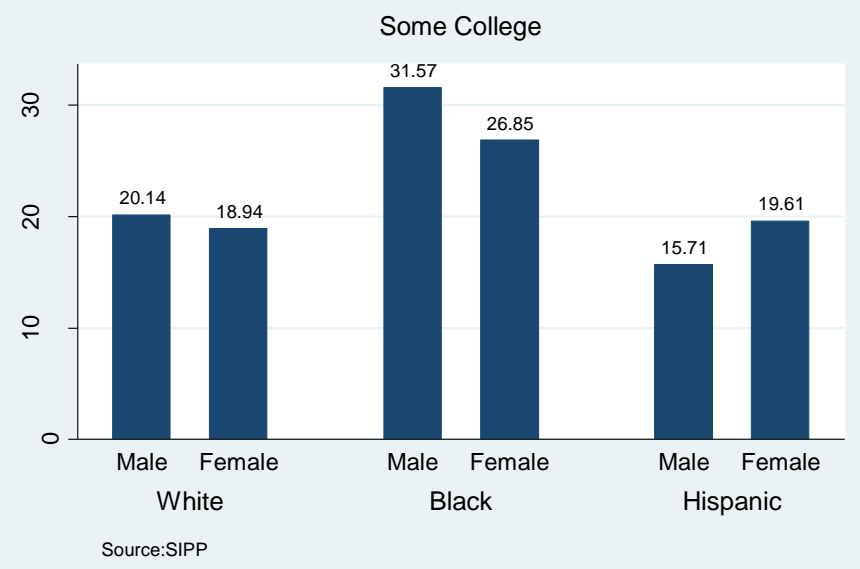




\begin{tabular}{|c|c|c|c|c|c|c|}
\hline \multicolumn{7}{|c|}{ Table 1(B) - Educational Attainment by Race/Gender - Ages 25-29 } \\
\hline Race & Gender & \begin{tabular}{|c|} 
Education \\
\end{tabular} & 1990 & 2001 & 2007 & 2010 \\
\hline \multirow{9}{*}{ Black } & \multirow{9}{*}{ Males } & Dropout & 0.2 & 0.14 & 0.09 & 0.11 \\
\hline & & GED & - & 0.1 & 0.02 & 0.04 \\
\hline & & High School Graduate & 0.44 & 0.29 & 0.3 & 0.28 \\
\hline & & Some College & - & 0.28 & 0.36 & 0.34 \\
\hline & & Certificate & 0.23 & 0.05 & 0.11 & 0.1 \\
\hline & & Associates & 0.02 & 0.03 & 0.03 & 0.05 \\
\hline & & Bachelors & 0.08 & 0.08 & 0.08 & 0.08 \\
\hline & & Masters & 0.02 & 0.03 & 0 & - \\
\hline & & Sample N & 694 & 747 & 292 & 694 \\
\hline \multirow{9}{*}{ Black } & \multirow{9}{*}{ Females } & Dropout & 0.17 & 0.14 & 0.15 & 0.1 \\
\hline & & GED & - & 0.07 & 0.08 & 0.05 \\
\hline & & High School Graduate & 0.42 & 0.26 & 0.13 & 0.17 \\
\hline & & Some College & 0.24 & 0.29 & 0.31 & 0.31 \\
\hline & & Certificate & 0.02 & 0.04 & 0.14 & 0.1 \\
\hline & & Associates & 0.04 & 0.03 & 0.06 & 0.11 \\
\hline & & Bachelors & 0.09 & 0.14 & 0.13 & 0.13 \\
\hline & & Masters & 0.01 & 0.04 & 0.01 & 0.02 \\
\hline & & Sample N & 1181 & 1110 & 431 & 879 \\
\hline \multirow{9}{*}{ Hispanic } & \multirow{9}{*}{ Males } & Dropout & 0.38 & 0.41 & 0.31 & 0.28 \\
\hline & & GED & - & 0.04 & 0.17 & 0.07 \\
\hline & & High School Graduate & 0.31 & 0.24 & 0.27 & 0.26 \\
\hline & & Some College & 0.16 & 0.16 & 0.11 & 0.17 \\
\hline & & Certificate & 0.02 & 0.02 & 0.05 & 0.07 \\
\hline & & Associates & 0.02 & 0.02 & 0.02 & 0.06 \\
\hline & & Bachelors & 0.1 & 0.08 & 0.06 & 0.07 \\
\hline & & Masters & 0 & 0.01 & 0.01 & 0 \\
\hline & & Sample N & 946 & 1309 & 387 & 904 \\
\hline \multirow{8}{*}{ Hispanic } & \multirow{8}{*}{ Females } & Dropout & 0.31 & 0.34 & 0.29 & 0.29 \\
\hline & & GED & - & 0.06 & 0.08 & 0.04 \\
\hline & & High School Graduate & 0.37 & 0.26 & 0.17 & 0.25 \\
\hline & & Some College & 0.2 & 0.16 & 0.2 & 0.2 \\
\hline & & Certificate & 0.02 & 0.03 & 0.07 & 0.08 \\
\hline & & Associates & 0.04 & 0.03 & 0.1 & 0.06 \\
\hline & & Bachelors & 0.06 & 0.1 & 0.08 & 0.07 \\
\hline & & Masters & 0.01 & 0.02 & 0.01 & 0.01 \\
\hline
\end{tabular}




\begin{tabular}{|c|c|c|c|c|c|c|}
\hline & & Sample N & 1002 & 1334 & 543 & 1127 \\
\hline \multirow{9}{*}{ Whites } & \multirow{9}{*}{ Males } & Dropout & 0.1 & 0.07 & 0.09 & 0.07 \\
\hline & & GED & - & 0.06 & 0.05 & 0.05 \\
\hline & & High School Graduate & 0.37 & 0.27 & 0.21 & 0.21 \\
\hline & & Some College & 0.2 & 0.22 & 0.25 & 0.22 \\
\hline & & Certificate & 0.03 & 0.03 & 0.07 & 0.06 \\
\hline & & Associates & 0.05 & 0.05 & 0.11 & 0.09 \\
\hline & & Bachelors & 0.2 & 0.25 & 0.2 & 0.27 \\
\hline & & Masters & 0.03 & 0.04 & 0.02 & 0.03 \\
\hline & & Sample N & 5786 & 4671 & 1797 & 4171 \\
\hline \multirow{9}{*}{ Whites } & \multirow{9}{*}{ Females } & Dropout & 0.09 & 0.06 & 0.07 & 0.04 \\
\hline & & GED & - & 0.05 & 0.05 & 0.04 \\
\hline & & High School Graduate & 0.37 & 0.18 & 0.17 & 0.16 \\
\hline & & Some College & 0.19 & 0.25 & 0.23 & 0.2 \\
\hline & & Certificate & 0.04 & 0.05 & 0.06 & 0.07 \\
\hline & & Associates & 0.07 & 0.06 & 0.1 & 0.1 \\
\hline & & Bachelors & 0.2 & 0.29 & 0.28 & 0.31 \\
\hline & & Masters & 0.04 & 0.06 & 0.03 & 0.07 \\
\hline & & Sample N & 6121 & 5072 & 2098 & 4531 \\
\hline
\end{tabular}

But an interesting pattern of educational progress appears across race groups in Table 1(B). While all groups show progress, the increases in BA attainment tend to be largest for whites in this time period, especially young whites. Among minorities, we see some notable declines in high school dropout rates; and attainment of sub-BA certificates and AAs rises quite substantially for most minority groups, especially after 2000. The greater increases in BA attainment among whites and in sub-BA attainment among minorities are also clear during the recessionary period of 2007-10.

Thus, the pattern of progress results in widening racial gaps in BA attainment and narrowing gaps in sub-BA attainment since 1990. The implications of these different patterns for labor market rewards are explored below, but the widening of the gap at the BA level (and above) likely reinforces higher earnings attainment for whites relative to minority groups.

The earnings gains associated with postsecondary education also differ quite substantially across the fields in which credentials are earned. Figure 3 presents summary results on field of concentration in 2010 for those who have earned certificates, AAs, BAs and advanced degrees. In Tables 2 and A2, we present the distributions of youth and all individuals respectively, by race and gender across fields. 
Figure 3: Field of Study by Degree

Field of Study By Degree, Ages 25-29, 2010

BA or Above

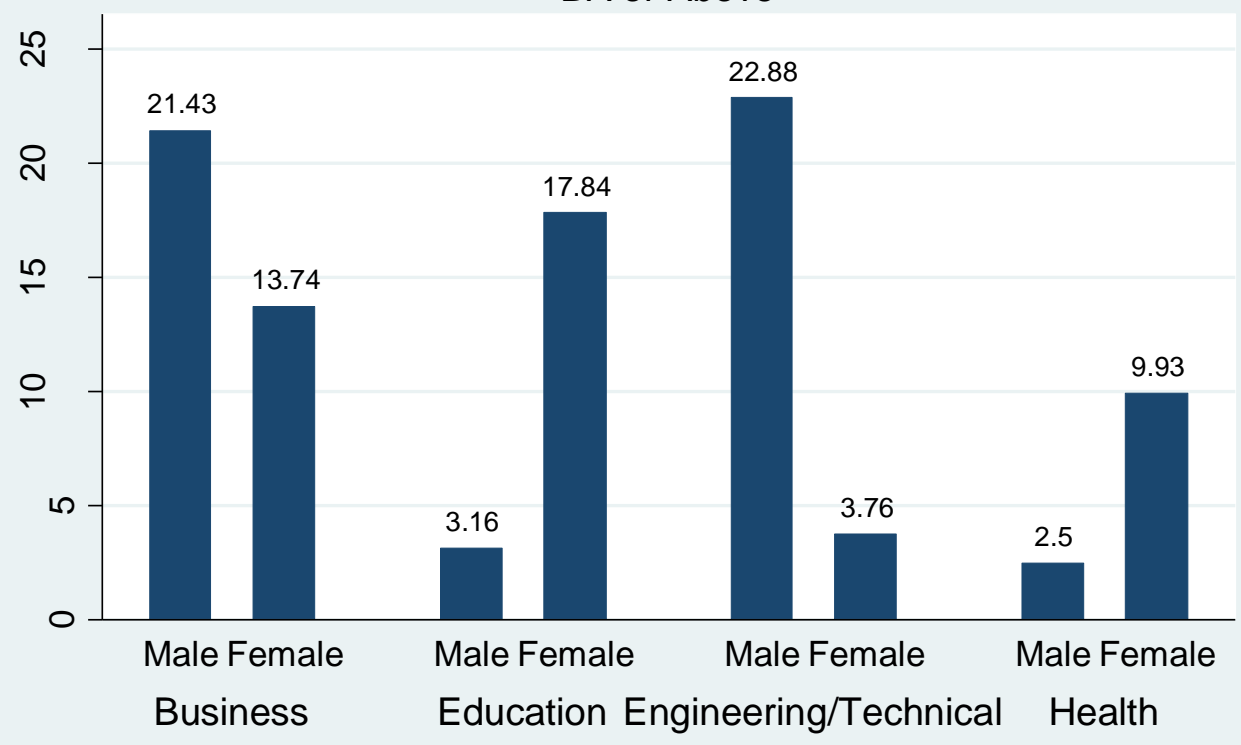

Source:SIPP

Field of Study By Degree, Ages 25-29, 2010

Certificates and $A A$

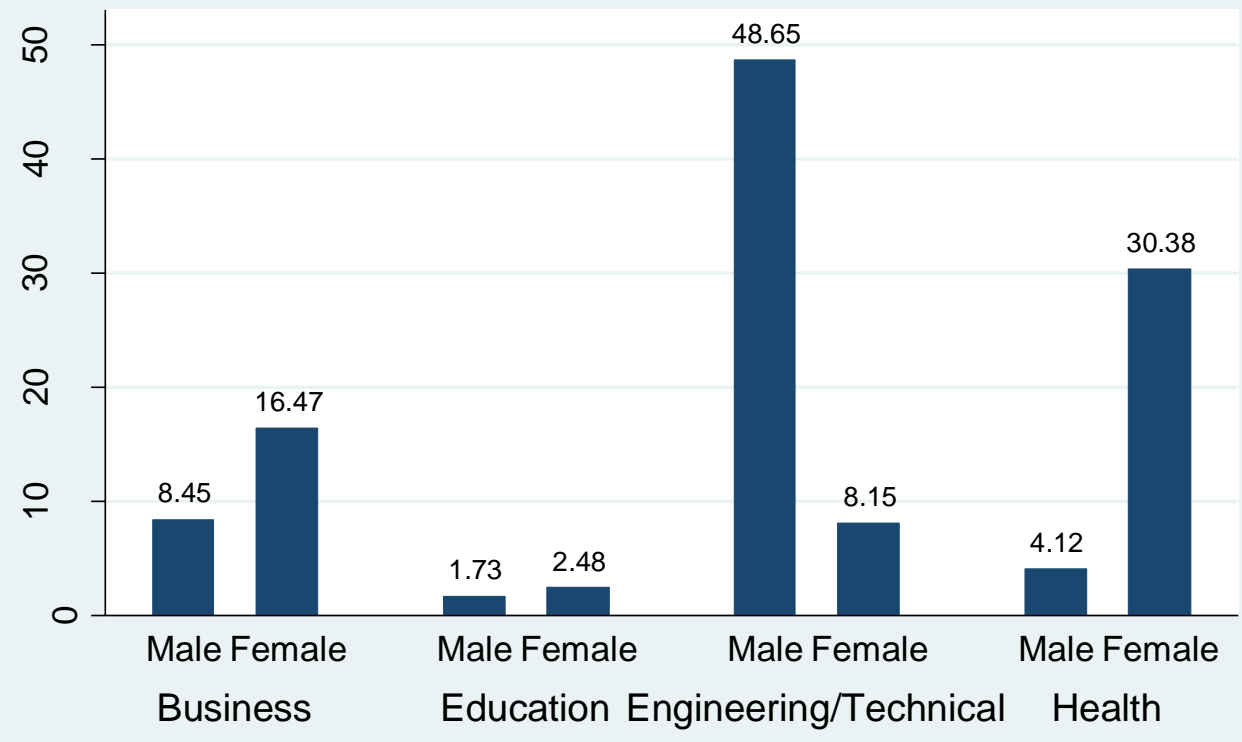

Source:SIPP 


\begin{tabular}{|c|c|c|c|c|c|c|}
\hline \multicolumn{7}{|c|}{$\begin{array}{c}\text { Table } 2 \text { - Distribution of People Across Field of Study } \\
\text { by Race and Gender in } 2010 \text { - Ages 25-29 }\end{array}$} \\
\hline & & \multicolumn{2}{|c|}{ Gender } & \multicolumn{3}{|c|}{ Race } \\
\hline Education & Field & Males & Females & Blacks & Hispanic & Whites \\
\hline \multirow{5}{*}{ Certificate } & Business & 0.02 & 0.16 & 0.11 & 0.09 & 0.10 \\
\hline & Engineering/Technical & 0.62 & 0.05 & 0.28 & 0.25 & 0.33 \\
\hline & Health & 0.03 & 0.37 & 0.26 & 0.17 & 0.22 \\
\hline & Other & 0.33 & 0.42 & 0.36 & 0.48 & 0.35 \\
\hline & Sample N & 435 & 587 & 165 & 151 & 637 \\
\hline \multirow{10}{*}{ Associates } & Arts/Humanities & 0.15 & 0.14 & 0.09 & 0.10 & 0.13 \\
\hline & Business & 0.15 & 0.19 & 0.17 & 0.23 & 0.18 \\
\hline & Communications & 0.01 & 0.01 & 0.03 & - & 0.01 \\
\hline & Education & 0.03 & 0.05 & 0.10 & 0.09 & 0.03 \\
\hline & Engineering/Technical & 0.35 & 0.12 & 0.20 & 0.22 & 0.23 \\
\hline & Health & 0.06 & 0.24 & 0.07 & 0.19 & 0.17 \\
\hline & Natural Sciences & 0.02 & 0.02 & 0.05 & - & 0.02 \\
\hline & Other & 0.22 & 0.19 & 0.26 & 0.15 & 0.21 \\
\hline & Social Sciences & 0.01 & 0.05 & 0.03 & 0.02 & 0.03 \\
\hline & Sample N & 488 & 664 & 106 & 113 & 805 \\
\hline \multirow{10}{*}{ Bachelors } & Arts/Humanities & 0.14 & 0.15 & 0.04 & 0.21 & 0.15 \\
\hline & Business & 0.22 & 0.14 & 0.19 & 0.25 & 0.18 \\
\hline & Communications & 0.04 & 0.06 & 0.05 & 0.10 & 0.04 \\
\hline & Education & 0.03 & 0.15 & 0.18 & 0.05 & 0.10 \\
\hline & Engineering/Technical & 0.22 & 0.04 & 0.09 & - & 0.11 \\
\hline & Health & 0.02 & 0.09 & 0.05 & 0.04 & 0.05 \\
\hline & Natural Sciences & 0.08 & 0.08 & 0.10 & 0.09 & 0.08 \\
\hline & Other & 0.15 & 0.17 & 0.15 & 0.19 & 0.17 \\
\hline & Social Sciences & 0.10 & 0.12 & 0.14 & 0.07 & 0.12 \\
\hline & Sample N & 1351 & 1715 & 143 & 136 & 2490 \\
\hline \multirow{11}{*}{ Advanced } & Arts/Humanities & 0.04 & 0.06 & 0.15 & - & 0.06 \\
\hline & Business & 0.13 & 0.08 & - & - & 0.10 \\
\hline & Communications & 0.02 & 0.03 & - & 0.14 & 0.02 \\
\hline & Education & 0.07 & 0.36 & - & 0.53 & 0.30 \\
\hline & Engineering/Technical & 0.26 & 0.04 & - & - & 0.07 \\
\hline & Health & 0.14 & 0.11 & - & - & 0.10 \\
\hline & Law & 0.09 & 0.08 & 0.51 & 0.33 & 0.04 \\
\hline & Natural Sciences & 0.06 & 0.05 & - & - & 0.06 \\
\hline & Other & 0.20 & 0.20 & 0.35 & - & 0.24 \\
\hline & Social Sciences & - & - & - & - & - \\
\hline & Sample N & 170 & 359 & 12 & 16 & 396 \\
\hline
\end{tabular}


While it is difficult to discern consistent differences in field of concentration by race (especially given the small sample sizes of minority youth), the differences across genders are quite pronounced. At the sub-BA level, women are more concentrated in health, education and business than are men, while men are more concentrated in engineering/technical fields and in natural sciences. Also, at the BA level, men start to be more concentrated in business than women. The concentrations of men in business and health care also grow among those with advanced degrees. These patterns largely hold for youth as well as for all age groups (though the sample for the former are quite small). The implications of this gender gap in fields of concentration for the earnings gender gap are considered below.

\section{Employment and Earnings}

We now begin to explore the labor market outcomes associated with these differences in educational attainment. We present employment rates and mean hourly wages at each level of education in 2010 (for the youth sample) in Figure 4 and also by race and gender for those aged 25-29 and for all workers in Tables 3 and A3, respectively. 
Figure 4: Employment and Wages by Education, 2010

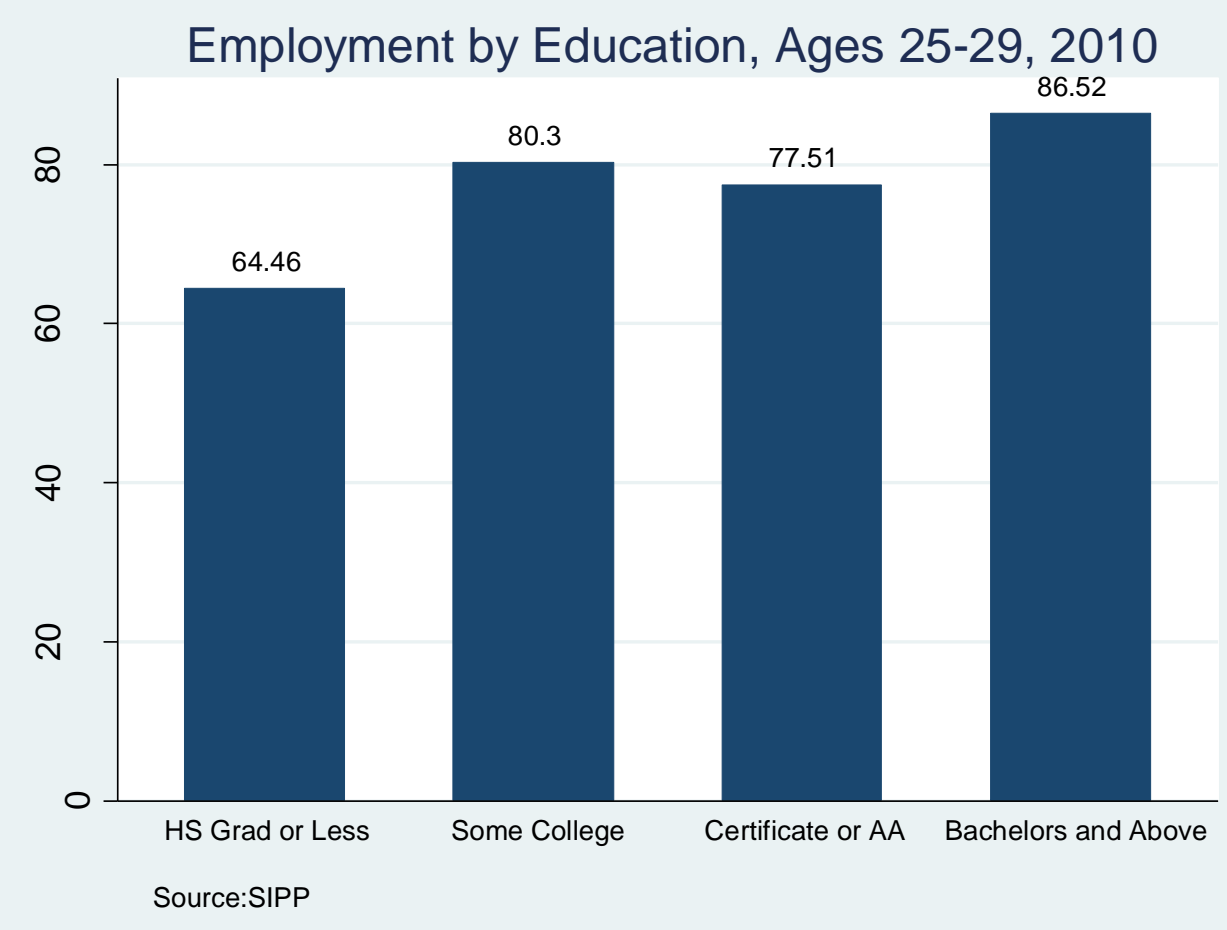

Wages by Education, Ages 25-29, 2010

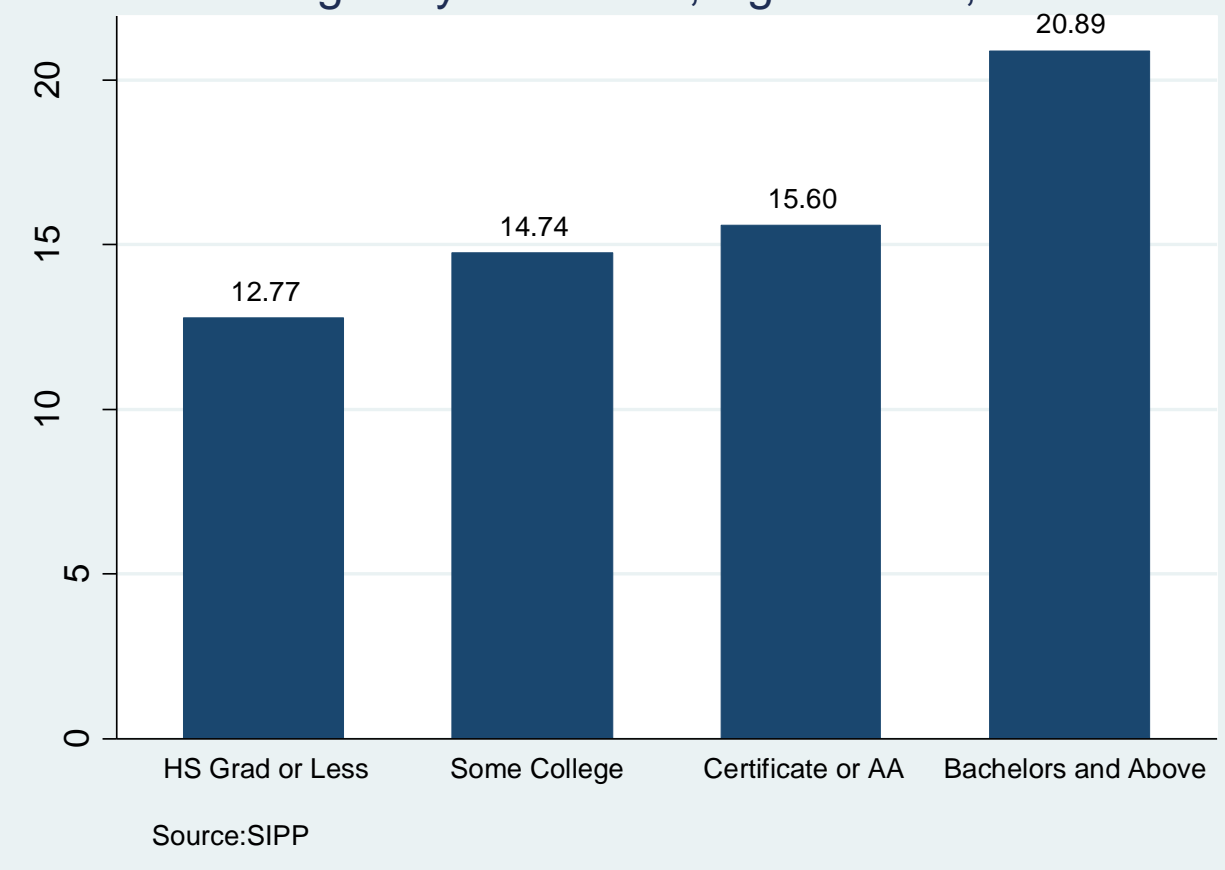




\begin{tabular}{|c|c|c|c|c|c|}
\hline \multicolumn{6}{|c|}{$\begin{array}{l}\text { Table } 3 \text { - Employment Rate and Mean Hourly Wages } \\
\text { by Education by Race/Gender in } 2010 \text { - Ages } 25-29\end{array}$} \\
\hline Education & Race & Gender & Employment Rate & $\mathrm{N}$ & $\begin{array}{l}\text { Mean Hourly Wage } \\
\text { (in } 2010 \$)\end{array}$ \\
\hline \multirow{6}{*}{ Dropout } & \multirow{2}{*}{ Black } & Male & 0.43 & 61 & $\$ 9.58$ \\
\hline & & Female & 0.33 & 107 & $\$ 9.69$ \\
\hline & \multirow{2}{*}{ Hispanic } & Male & 0.74 & 276 & $\$ 10.93$ \\
\hline & & Female & 0.35 & 342 & $\$ 8.14$ \\
\hline & \multirow{2}{*}{ White } & Male & 0.73 & 302 & $\$ 12.60$ \\
\hline & & Female & 0.49 & 250 & $\$ 10.12$ \\
\hline \multirow{6}{*}{ GED } & \multirow{2}{*}{ Black } & Male & 0.40 & 25 & $\$ 11.08$ \\
\hline & & Female & 0.56 & 60 & $\$ 11.32$ \\
\hline & \multirow{2}{*}{ Hispanic } & Male & 0.87 & 73 & $\$ 13.08$ \\
\hline & & Female & 0.55 & 54 & $\$ 8.33$ \\
\hline & \multirow{2}{*}{ White } & Male & 0.56 & 214 & $\$ 15.21$ \\
\hline & & Female & 0.59 & 192 & $\$ 12.55$ \\
\hline \multirow{6}{*}{ High School } & \multirow{2}{*}{ Black } & Male & 0.73 & 147 & $\$ 12.43$ \\
\hline & & Female & 0.57 & 159 & $\$ 9.64$ \\
\hline & \multirow{2}{*}{ Hispanic } & Male & 0.76 & 245 & $\$ 13.60$ \\
\hline & & Female & 0.47 & 262 & $\$ 11.22$ \\
\hline & \multirow{2}{*}{ White } & Male & 0.83 & 905 & $\$ 16.29$ \\
\hline & & Female & 0.68 & 747 & $\$ 12.14$ \\
\hline \multirow{6}{*}{ Some College } & \multirow{2}{*}{ Black } & Male & 0.78 & 161 & $\$ 13.59$ \\
\hline & & Female & 0.89 & 236 & $\$ 13.47$ \\
\hline & \multirow{2}{*}{ Hispanic } & Male & 0.81 & 142 & $\$ 12.55$ \\
\hline & & Female & 0.66 & 221 & $\$ 13.77$ \\
\hline & \multirow{2}{*}{ White } & Male & 0.92 & 840 & $\$ 16.55$ \\
\hline & & Female & 0.77 & 858 & $\$ 14.42$ \\
\hline \multirow{6}{*}{ Certificate } & \multirow{2}{*}{ Black } & Male & 0.51 & 58 & $\$ 11.45$ \\
\hline & & Female & 0.73 & 107 & $\$ 11.93$ \\
\hline & \multirow{2}{*}{ Hispanic } & Male & 0.89 & 56 & $\$ 12.17$ \\
\hline & & Female & 0.63 & 95 & $\$ 13.81$ \\
\hline & \multirow{2}{*}{ White } & Male & 0.86 & 283 & $\$ 16.95$ \\
\hline & & Female & 0.67 & 354 & $\$ 13.42$ \\
\hline \multirow{6}{*}{ Associates } & \multirow{2}{*}{ Black } & Male & 0.90 & 22 & $\$ 11.90$ \\
\hline & & Female & 0.76 & 84 & $\$ 12.35$ \\
\hline & \multirow{2}{*}{ Hispanic } & Male & 1.00 & 52 & $\$ 17.03$ \\
\hline & & Female & 0.74 & 61 & $\$ 16.32$ \\
\hline & IXhite & Male & 0.88 & 355 & $\$ 17.13$ \\
\hline & White & Female & 0.79 & 450 & $\$ 17.77$ \\
\hline & & Male & 0.96 & 36 & $\$ 20.24$ \\
\hline & Black & Female & 0.79 & 107 & $\$ 16.11$ \\
\hline & & Male & 0.65 & 52 & $\$ 14.94$ \\
\hline Bachelors & Hispanic & Female & 0.70 & 84 & $\$ 15.96$ \\
\hline & & \begin{tabular}{|l} 
Male \\
\end{tabular} & 0.93 & 1131 & $\$ 21.40$ \\
\hline & White & Female & 0.87 & 1359 & $\$ 18.63$ \\
\hline
\end{tabular}


Most differences in labor market outcomes across educational groups are fairly well known at this point. Both employment and wages tend to rise with higher educational attainment, for all workers and the younger cohorts. The apparent relative returns to "some college" and sub-BA degrees relative to high school only are also noteworthy.

Of course, these summary measures do not control for any personal characteristics of individuals or different levels of academic achievement; and the extent to which they are causal, or reflective of unobserved personal factors, is unclear at this point. Still, the relative returns suggest there is some value to all postsecondary credentials, including certificates and AA degrees as well as BA and higher, relative to high school only.

In the data by race and gender in Table 3, we find that employment rates are strikingly low for female high school dropouts and also for those who are black males, while they are relatively high for Hispanic male dropouts (many of whom might be immigrants). Even within educational categories, notable wage and employment differences are found by gender and by race, with males working more and earning more than females (in most cases) and whites earning more than blacks or Hispanics.

Finally, in Figure 5 we consider labor market outcomes for those with postsecondary credentials by field of concentration. We find higher wages among those with engineering/technical fields for most credentials. Outcomes for those with any field of certificates are comparable or higher than those with high school degrees only (comparing Figure 4 and Table 4). We begin to see stronger returns to health care and business at the AA level and especially at the BA level. It is noteworthy that females tend to be underrepresented in the high-earning fields, especially engineering/technical areas and natural sciences/math, relative to males; and, when returns to some fields (like business) rise especially at the BA level, the relative concentrations of males rise as well. 
Figure 5: Wages by Field of Study and Degree, 2010

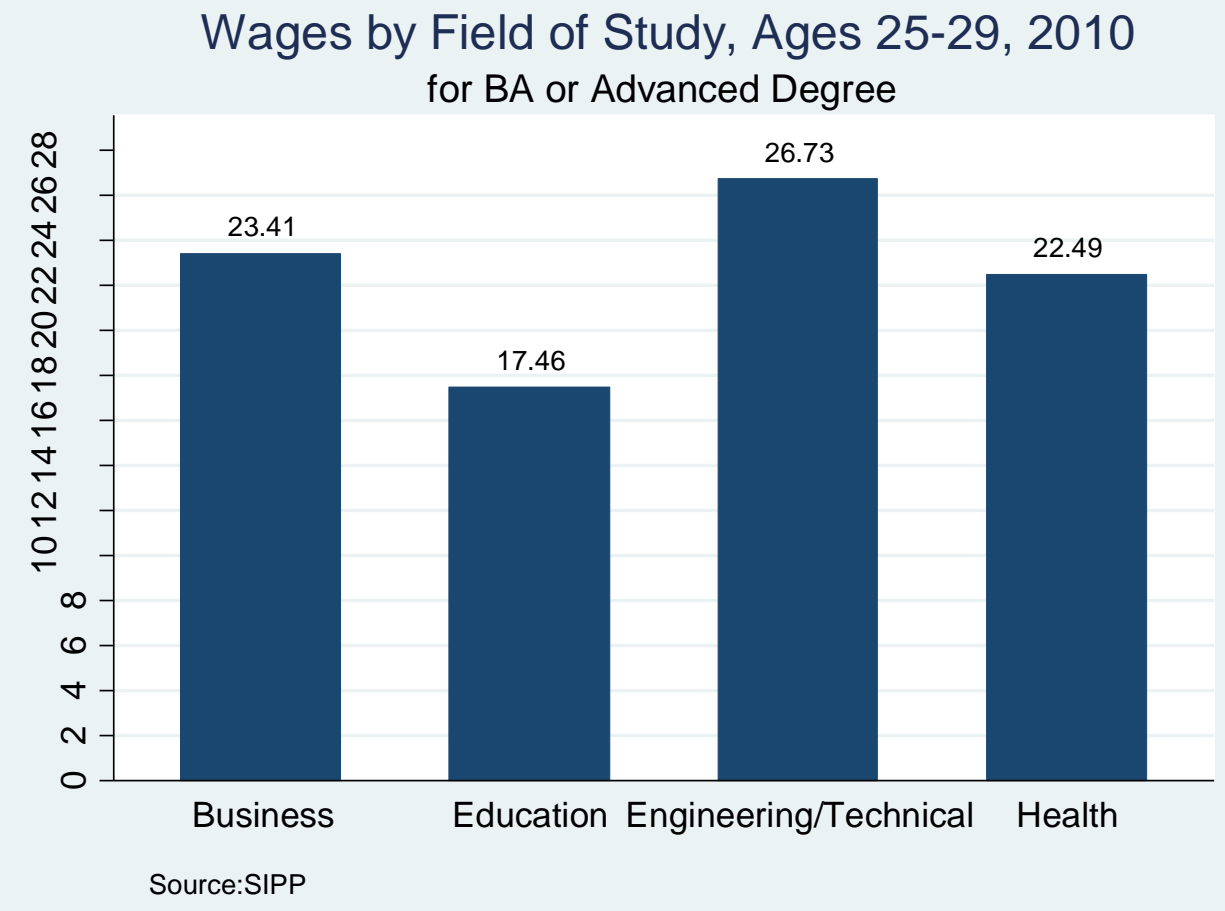

Wages by Field of Study, Ages 25-29, 2010 for Certificates and AA

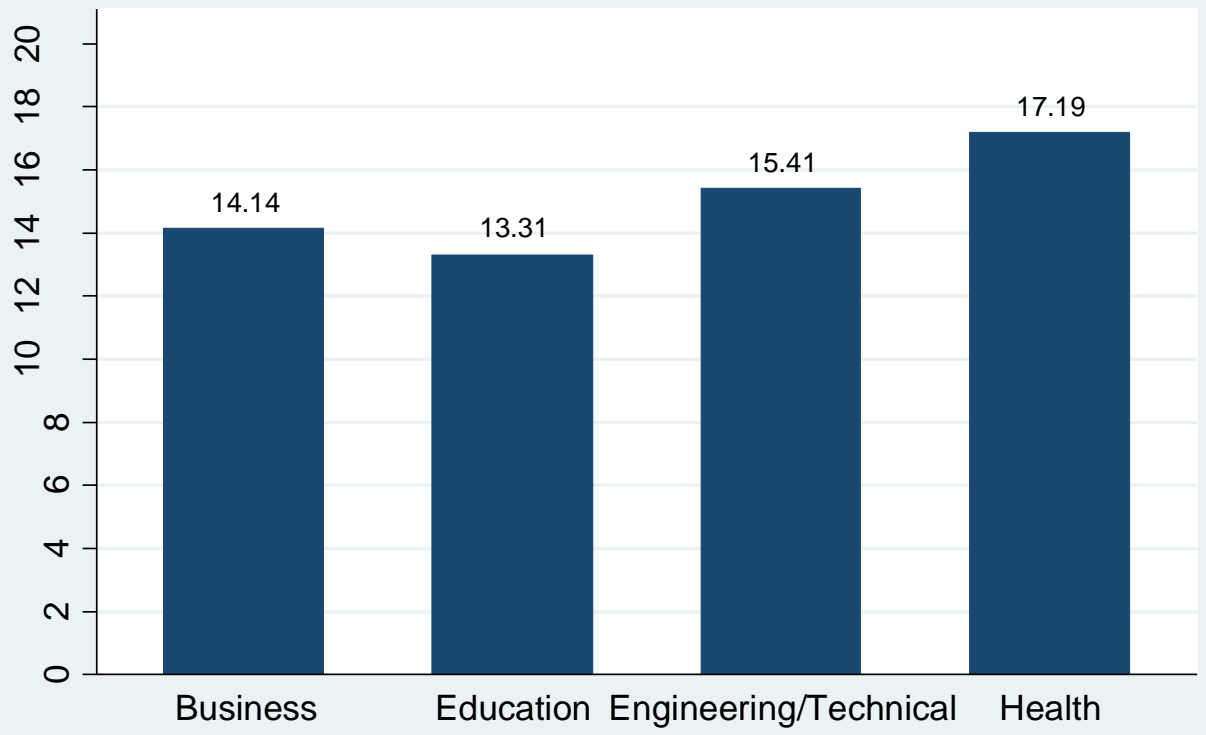

Source:SIPP 


\begin{tabular}{|c|c|c|c|c|}
\hline \multicolumn{5}{|c|}{$\begin{array}{c}\text { Table } 4 \text { - Employment Rate and Mean Hourly Wages } \\
\text { by Degree/Fields of Study in } 2010 \text { - Ages } 25-29\end{array}$} \\
\hline Education & Field & $\begin{array}{l}\text { Employment } \\
\text { Rate }\end{array}$ & $\mathrm{N}$ & $\begin{array}{l}\text { Mean Wage } \\
\text { (in } 2010 \$ \text { ) }\end{array}$ \\
\hline \multirow{4}{*}{ Certificate } & Health & 0.68 & 239 & $\$ 14.15$ \\
\hline & Business & 0.69 & 88 & $\$ 12.03$ \\
\hline & Engineering/Technical & 0.80 & 312 & $\$ 14.54$ \\
\hline & Other & 0.70 & 383 & $\$ 14.28$ \\
\hline \multirow{9}{*}{ Associates } & Health & 0.86 & 179 & $\$ 21.07$ \\
\hline & Arts/Humanities & 0.80 & 152 & $\$ 16.34$ \\
\hline & Education & 0.72 & 47 & $\$ 14.15$ \\
\hline & Communications & 1.00 & 14 & $\$ 14.55$ \\
\hline & Business & 0.84 & 196 & $\$ 15.64$ \\
\hline & Engineering/Technical & 0.86 & 239 & $\$ 16.22$ \\
\hline & Social Sciences & 0.49 & 38 & $\$ 13.76$ \\
\hline & Natural Sciences/Math & 0.78 & 23 & $\$ 14.18$ \\
\hline & Other & 0.82 & 264 & $\$ 16.15$ \\
\hline \multirow{9}{*}{ Bachelors } & Health & 0.84 & 184 & $\$ 19.79$ \\
\hline & Arts/Humanities & 0.86 & 432 & $\$ 17.38$ \\
\hline & Education & 0.90 & 295 & $\$ 16.22$ \\
\hline & Communications & 0.92 & 146 & $\$ 18.80$ \\
\hline & Business & 0.90 & 554 & $\$ 22.14$ \\
\hline & Engineering/Technical & 0.86 & 359 & $\$ 25.64$ \\
\hline & Social Sciences & 0.85 & 338 & $\$ 17.50$ \\
\hline & Natural Sciences/Math & 0.81 & 248 & $\$ 18.81$ \\
\hline & Other & 0.83 & 510 & $\$ 20.43$ \\
\hline \multirow{10}{*}{ Advanced } & Health & 0.89 & 60 & $\$ 25.48$ \\
\hline & Arts/Humanities & 0.81 & 29 & $\$ 16.17$ \\
\hline & Education & 0.84 & 123 & $\$ 21.42$ \\
\hline & Communications & 1.00 & 8 & $\$ 18.90$ \\
\hline & Business & 0.93 & 57 & $\$ 28.64$ \\
\hline & Engineering/Technical & 0.87 & 67 & $\$ 28.70$ \\
\hline & Social Sciences & 0.93 & 77 & $\$ 18.27$ \\
\hline & Natural Sciences/Math & 0.90 & 34 & $\$ 18.60$ \\
\hline & Law & 0.92 & 40 & $\$ 37.81$ \\
\hline & Other & 0.83 & 111 & $\$ 25.56$ \\
\hline
\end{tabular}




\section{B. NELS Data}

As noted earlier, we use the NELS data from the 2000 wave of the survey of the $8^{\text {th }}$ grade class of 1988. Though limited to this one relatively youthful cohort of workers, the NELS provides richer information on measures of academic achievement and also on family SES (as well as race and gender) than does the SIPP.

In particular, socioeconomic status (SES) is an index based on parental relative standing in education, occupation, and household income. Math and reading scores are obtained from a test administered in grade 12; we also include numbers of math/science and English classes taken, as well as average grades in these classes, where the latter are measured on a scale of 1-13 (with 1 being the highest). ${ }^{5}$

Figure 6 and Table 5 presents cross-tabulations of various measures of academic achievement in high school with demographic characteristics such as race, gender and low family SES.

Specifically, in Table 5 we measure the likelihood of scoring in the bottom quartiles of a test on reading and math, as well as mean grades and numbers of courses taken in math/science and English, for each race/gender group and for those in the bottom quartile of family SES. The different concentrations among the low achievers on tests by race/gender and SES are also presented in Figure 6.

\footnotetext{
${ }^{5}$ The tests were administered to students in school year 1991-92 when most students were in the $12^{\text {th }}$ grade. Data on courses taken and grade received are taken from school transcripts for grades 9-12. SES is computed by NELS based on data on parental education, occupation and total household income as of 1992.
} 
Figure 6: High School Achievement by Demographic Group

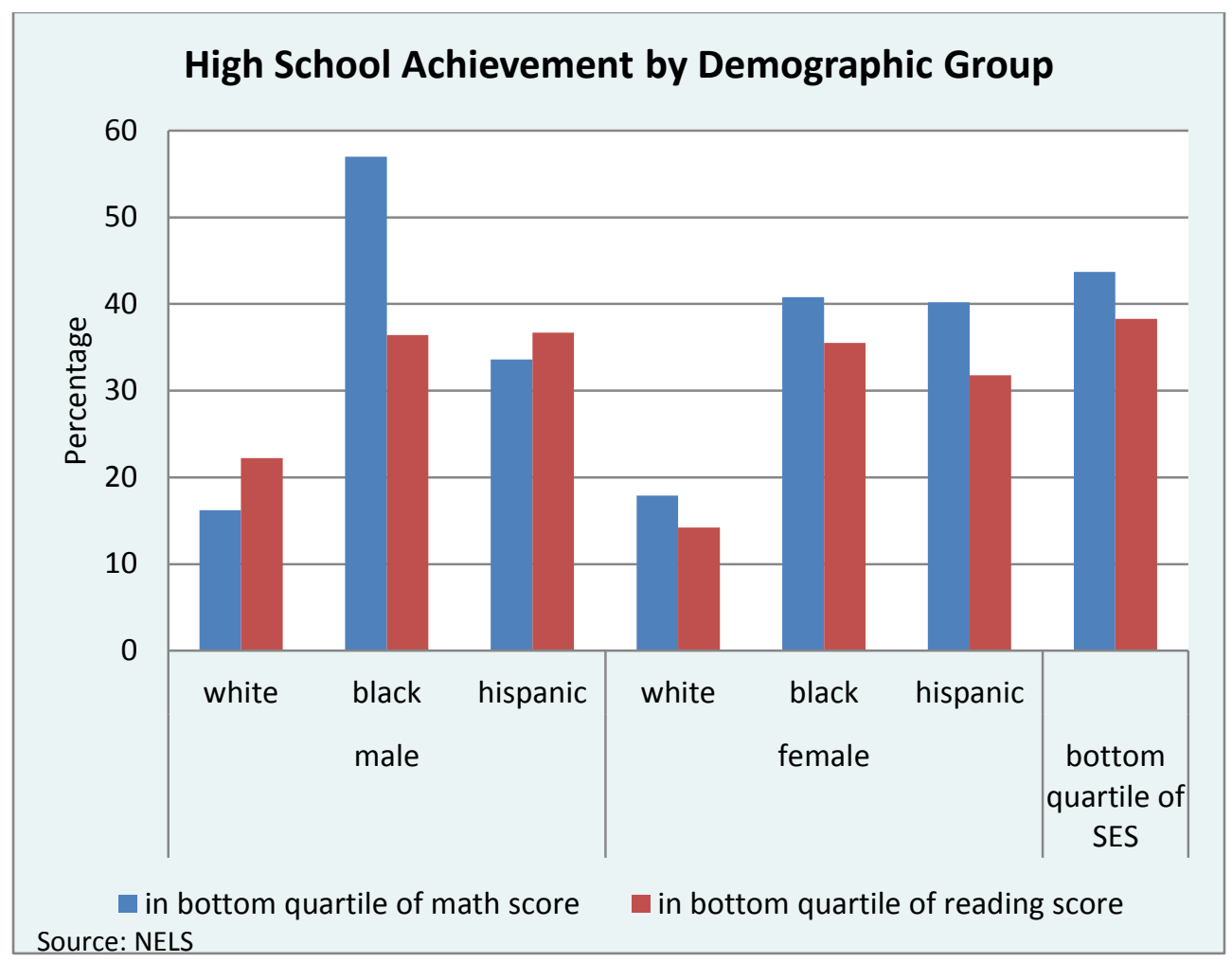




\begin{tabular}{|c|c|c|c|c|c|c|c|}
\hline & \multicolumn{3}{|c|}{ Male } & \multicolumn{3}{|c|}{ Female } & \multirow[b]{2}{*}{$\begin{array}{c}\text { Bottom Quartile } \\
\text { of SES }\end{array}$} \\
\hline Educational Attainment & White & Black & Hispanic & White & Black & Hispanic & \\
\hline $\begin{array}{l}\text { In Bottom Quartile of } \\
\text { Math Score }(\%)\end{array}$ & 16.2 & 57 & 33.6 & 17.9 & 40.8 & 40.2 & 43.7 \\
\hline $\begin{array}{c}\text { In Bottom Quartile of Reading } \\
\text { Score }(\%)\end{array}$ & 22.2 & 36.4 & 36.7 & 14.2 & 35.5 & 31.8 & 38.3 \\
\hline Mean Grade in & 7.2 & 9.1 & 8.2 & 6.6 & 8.2 & 7.8 & 8.2 \\
\hline Math/Science Classes & $(2.5)$ & $(1.8)$ & $(2.4)$ & $(2.4)$ & (2.3) & $(2.3)$ & $(2.3)$ \\
\hline Mean Grade in & 7.4 & 8.9 & 8.4 & 6.2 & 8.1 & 7.6 & 8.5 \\
\hline English Classes & $(2.7)$ & $(1.8)$ & $(2.5)$ & $(2.6)$ & $(2.5)$ & $(2.6)$ & $(2.6)$ \\
\hline Mean Courses in & 6.2 & 5.8 & 5.3 & 6.3 & 5.8 & 5.3 & 4.8 \\
\hline Math/Science & $(2.4)$ & $(2.5)$ & $(2.5)$ & $(2.3)$ & $(2.7)$ & $(2.4)$ & $(2.5)$ \\
\hline Mean Courses in & 3.6 & 3.7 & 3.5 & 3.8 & 3.6 & 3.5 & 3.2 \\
\hline English & $(1.2)$ & $(1.2)$ & $(1.5)$ & $(1.1)$ & (1.4) & $(1.5)$ & (1.6) \\
\hline
\end{tabular}

*Note: Grades measured on 1-13 scale (1=highest). For the entries on English and math and science attainment, the mean values are on the top rows and the standard deviations are on the lower rows, in parenthesis.

The results show, as expected, that race, gender and family background are correlated with various measures of achievement. Whites are less likely than blacks or Hispanics to be found in the bottom quartiles of the test distribution in Figure 6, and they get higher grades in both math/science and English classes in Table 5. Young women tend to outperform men in reading tests and to underperform on math tests (except among blacks) and their grades in both math/science and English courses are higher.

Notably, students from low SES families tend to have lower achievement on average than minorities. Their test scores are generally lower (except relative to black males in math), their grades in math/science are comparable to those of minority groups, and their grades in English are generally lower.

In Table 6 we present summary measures of educational attainment by race/gender and family SES (part A) and by being in the bottom quartile of achievement measures (part B). We now have separate measures of attendance and non-completion at 2-year and 4-year colleges as well. The results show levels of educational attainment quite comparable to those that appear in the SIPP data for the 25-29 year old age cohort of 2007-2010, but a bit higher in a few categories. 


\begin{tabular}{|c|c|c|c|c|c|c|c|c|}
\hline & Overall & & $\mathrm{Mal}$ & & & Fema & & \\
\hline Educational Attainment & Overall & White & Black & Hispanic & White & Black & Hispanic & $\begin{array}{l}\text { Bottom } \\
\text { Quartile } \\
\text { of SES }\end{array}$ \\
\hline Dropout & .11 & .09 & .12 & .19 & .09 & .14 & .22 & .25 \\
\hline High School Graduate & .16 & .18 & .26 & .16 & .14 & .11 & .14 & .26 \\
\hline $\begin{array}{c}\text { Attended 2-Year College; } \\
\text { No Credential }\end{array}$ & .13 & .15 & .14 & .17 & .11 & .16 & .10 & .09 \\
\hline Certificate & .09 & .08 & .21 & .06 & .09 & .16 & .11 & .12 \\
\hline AA & .07 & .07 & .04 & .07 & .08 & .06 & .07 & .06 \\
\hline $\begin{array}{c}\text { Attended 4-Year College; } \\
\text { No Credential }\end{array}$ & .15 & .13 & .12 & .21 & .14 & .17 & .23 & .15 \\
\hline $\mathrm{BA}$ & .26 & .27 & .11 & .12 & .32 & .20 & .12 & .07 \\
\hline$\overline{\mathrm{MA}}$ & .03 & .03 & .00 & .01 & .04 & .01 & .01 & .00 \\
\hline
\end{tabular}

*Note: Grades measured on 1-13 scale

(1=highest)

Table 6(B) - Educational Attendance and Completion by Bottom Quartile of Test Scores

\begin{tabular}{|c|c|c|}
\hline \hline Educational Attainment & Math Test Scores & Reading Test Scores \\
\hline Dropout & 0.18 & 0.15 \\
\hline $\begin{array}{c}\text { High School Graduate } \\
\begin{array}{c}\text { Attended 2-Year College; No } \\
\text { Credential }\end{array}\end{array}$ & 0.29 & 0.28 \\
\hline Certificate & 0.08 & 0.11 \\
\hline AA & 0.16 & 0.12 \\
\hline $\begin{array}{c}\text { Attended 4-Year College; No } \\
\text { Credential }\end{array}$ & 0.06 & 0.05 \\
\hline BA & 0.19 & 0.19 \\
\hline MA & 0.04 & 0.1 \\
\hline
\end{tabular}


Most of these findings are very consistent with what we observed earlier in the SIPP data, but we also see now that those in the bottom quartile of SES have higher dropout rates and lower attainment of BAs than any minority group. Table 6(B) also shows that being in the bottom quartile of almost any measure of academic achievement results in lower educational attainment than we observe for any race/gender group and comparable or lower than what we observe for the bottom quartile of SES. High school dropout rates are higher and BA attainment is lower than for most race/gender groups. Having lower reading scores and fewer English classes appears less harmful to educational attainment than having low achievement along other measures.

Since the NELS data provide separate information on attendance without credential attainment for 2-year and 4-year colleges, we can calculate completion rates of various credentials at each, conditional on attendance. In Figure 7 we present these completion rates by race/gender, family SES or lowest quartile of achievement. Completion rates are calculated for the attainment of AA degrees only or AAs as well as certificates for 2-year colleges, while BA completion is measured for the 4-year colleges. 
Figure 7: Completion Rates: Total and by Demographic/Achievement Groups

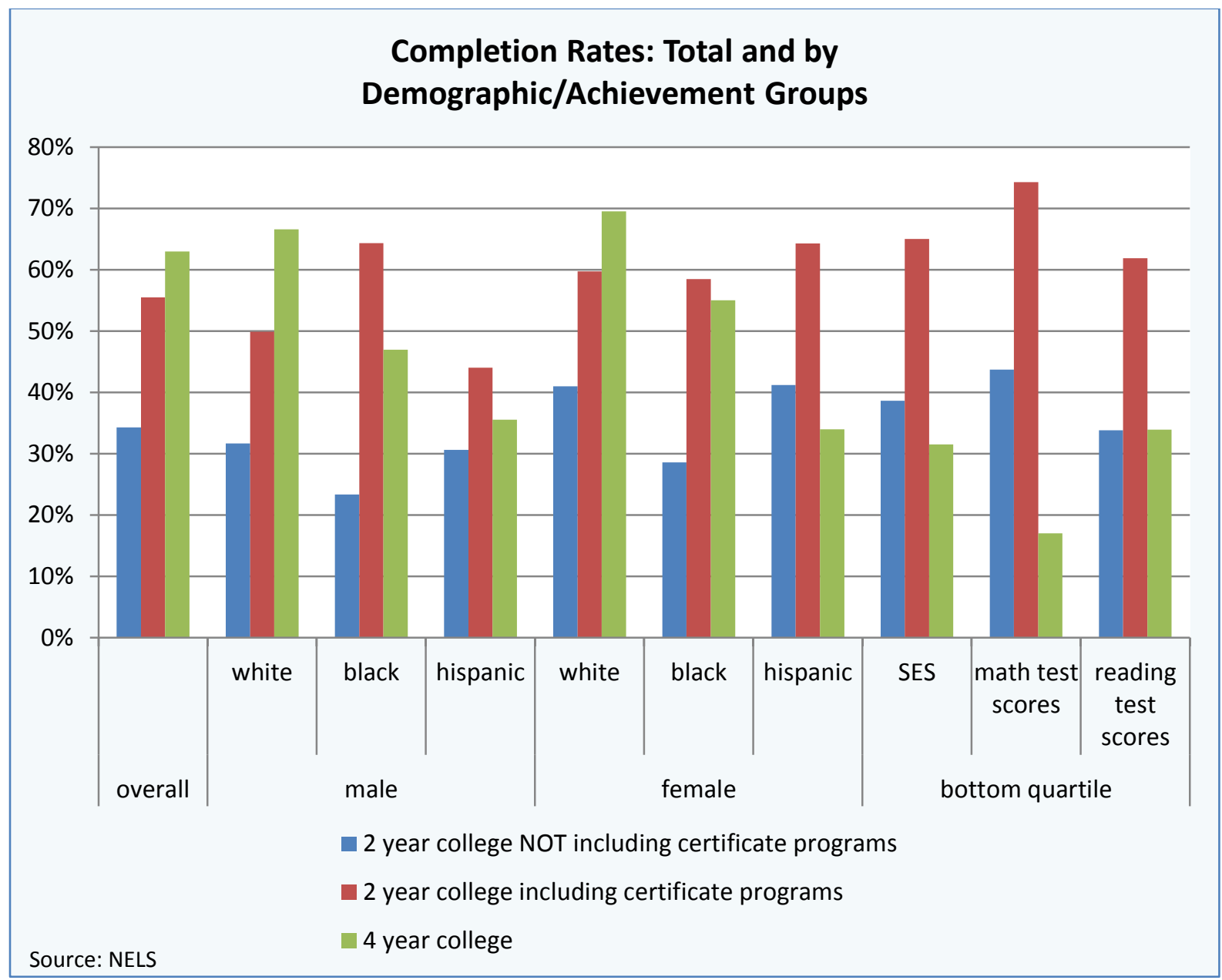

The results of Figure 7 are quite striking. For those who are about 26 years old in 2000, college completion rates overall are about $63 \%$ at 4 -year schools and are $34 \%$ (without certificates) or $55 \%$ (with certificates) at 2-year schools. ${ }^{6}$ Completion rates at 2-year colleges are somewhat lower for blacks than for whites and Hispanics when measured only by AA attainment, and they are more comparable (and higher for black males) when we include certificates. In contrast, completion rates at 4-year colleges are considerably lower for minorities and among those in the bottom SES quartile compared to the entire sample. Indeed, completion rates among whites are nearly $70 \%$ at 4 -year colleges, while they are 47 and $55 \%$ for black males and females respectively and just 34-36\% for Hispanics. Those in the bottom quartile of family SES complete 4 -year colleges at a rate of only $32 \%$. In virtually all cases, females are more likely to complete

\footnotetext{
${ }^{6}$ These are roughly 8 -year completion rates after high school, which should be sufficient to capture most BA attainment but much less among those earning advanced degrees. For evidence that time to completion of postsecondary degrees has slowed considerably over the past few decades see Turner (2007).
} 
college than are males. This stands in contrast to our estimated completion rates for students from low SES families at 2-year colleges, which are high relative to other groups.

Completion rates for those in the bottom quartiles of various achievement measures are relatively high at 2-year colleges and very low at 4-year colleges, especially for those with low math test scores and weak grades and course taking in math. Indeed, completion rates are under $20 \%$ at 4 -year colleges for those in the latter categories.

\section{A Few Regression Estimates}

In Tables 7 and beyond, we turn to regression estimates of the determinants of educational and labor market outcomes for these groups. Tables 7-9 focus on completion rates among those who attended 2-year colleges (excluding or including those obtaining certificates in Tables 7 and 8 respectively) or 4-year colleges (Table 9). Each of these tables presents results of regression equations for college completion using four specifications of covariates: race and gender only; race, gender and SES; race, gender and high school achievement measures; and race, gender and SES along with high school achievement. 


\begin{tabular}{|c|c|c|c|c|}
\hline & $\underline{1}$ & $\underline{2}$ & $\underline{3}$ & $\underline{4}$ \\
\hline \multicolumn{5}{|c|}{ Demographic Characteristics } \\
\hline \multirow[t]{2}{*}{ Female } & .45 & .38 & .36 & .30 \\
\hline & $(3.39)$ & $(2.9)$ & $(2.67)$ & $(2.29)$ \\
\hline \multirow[t]{2}{*}{ Black } & -.62 & -.76 & -.79 & -.89 \\
\hline & $(-2.18)$ & $(-2.71)$ & $(-2.96)$ & $(-3.33)$ \\
\hline \multirow[t]{2}{*}{ Hispanic } & -.07 & -.37 & -.34 & -.55 \\
\hline & $(-.31)$ & $(-1.54)$ & $(-1.45)$ & $(-2.27)$ \\
\hline \multirow[t]{2}{*}{ SES } & - & -.52 & - & -.42 \\
\hline & - & $(-5.12)$ & - & $(-3.84)$ \\
\hline \multicolumn{5}{|c|}{ High School Achievement } \\
\hline \multicolumn{5}{|c|}{ (Grades \& Standardized Scores) } \\
\hline \multirow[t]{2}{*}{ Math Score } & - & - & -.05 & -.05 \\
\hline & - & - & $(-4.44)$ & $(-4.04)$ \\
\hline \multirow[t]{2}{*}{ Reading Score } & - & - & .00 & .00 \\
\hline & - & - & $(-.37)$ & $(-.39)$ \\
\hline \multirow[t]{2}{*}{ Math/Science grades } & - & - & .12 & .11 \\
\hline & - & - & $(2.21)$ & $(1.98)$ \\
\hline \multirow[t]{2}{*}{ English Grades } & - & - & -.04 & -.03 \\
\hline & - & - & $(-.78)$ & $(-.64)$ \\
\hline $\mathrm{R}^{2}$ & .01 & .03 & .04 & .05 \\
\hline \multicolumn{5}{|c|}{$\begin{array}{l}\text { Note: The sample in this table }(\mathrm{N}=1,817) \text { includes two-year college attendees. The dependent variable is a dichotomous } \\
\text { indicator for whether respondents earned an AA degree. In this table and all other that follow, t-statistics are provided it } \\
\text { parenthesis below each coefficient. }\end{array}$} \\
\hline
\end{tabular}




\begin{tabular}{|c|c|c|c|c|}
\hline & $\underline{1}$ & $\underline{2}$ & $\underline{3}$ & $\underline{4}$ \\
\hline \multicolumn{5}{|c|}{ Demographic Characteristics } \\
\hline \multirow{2}{*}{ Female } & .38 & .27 & .29 & .21 \\
\hline & $(2.29)$ & $(1.59)$ & $(1.63)$ & $(1.16)$ \\
\hline \multirow{2}{*}{ Black } & .38 & .18 & -.19 & -.30 \\
\hline & $(.76)$ & $(.35)$ & $(-.52)$ & $(-.78)$ \\
\hline \multirow{2}{*}{ Hispanic } & -.09 & -.52 & -.51 & -.78 \\
\hline & $(-.51)$ & $(-2.65)$ & $(-2.5)$ & $(-3.72)$ \\
\hline \multirow{2}{*}{ SES } & - & -.71 & - & -.52 \\
\hline & - & $(-7.09)$ & - & $(-4.46)$ \\
\hline \multicolumn{5}{|l|}{ High School Achievement } \\
\hline \multirow{2}{*}{ Math Score } & - & - & -.09 & -.09 \\
\hline & - & - & $(-5.6)$ & $(-5.07)$ \\
\hline \multirow{2}{*}{ Reading Score } & - & - & .01 & .01 \\
\hline & - & - & $(.49)$ & $(.64)$ \\
\hline \multirow{2}{*}{ Math/Science grades } & - & - & .11 & .09 \\
\hline & - & - & $(2.13)$ & $(1.78)$ \\
\hline \multirow{2}{*}{ English Grades } & - & - & -.09 & -.08 \\
\hline & - & - & $(-2.01)$ & $(-1.72)$ \\
\hline $\mathrm{R}^{2}$ & .01 & .05 & .09 & .11 \\
\hline
\end{tabular}




\begin{tabular}{|c|c|c|c|c|}
\hline & $\underline{1}$ & $\underline{2}$ & $\underline{3}$ & $\underline{4}$ \\
\hline \multicolumn{5}{|c|}{ Demographic Characteristics } \\
\hline \multirow{2}{*}{ Female } & .32 & .50 & -.01 & .17 \\
\hline & $(2.73)$ & $(3.96)$ & $(-0.07)$ & $(.98)$ \\
\hline \multirow{2}{*}{ Black } & -.95 & -.47 & .65 & 1.00 \\
\hline & $(-4.21)$ & $(-1.9)$ & $(2.18)$ & $(3.14)$ \\
\hline \multirow{2}{*}{ Hispanic } & -1.33 & -.53 & -.57 & .13 \\
\hline & $(-6.52)$ & $(-2.48)$ & $(-2.62)$ & $(.59)$ \\
\hline \multirow{2}{*}{ SES } & - & 1.36 & - & 1.19 \\
\hline & - & $(15.85)$ & - & $(10.12)$ \\
\hline \multicolumn{5}{|c|}{$\begin{array}{l}\text { High School Achievement } \\
\text { (Grades \& Standardized Scores) }\end{array}$} \\
\hline \multirow{2}{*}{ Math Score } & - & - & .11 & .10 \\
\hline & - & - & $(8.08)$ & $(6.7)$ \\
\hline \multirow{2}{*}{ Reading Score } & - & - & .00 & -.01 \\
\hline & - & - & $(-0.21)$ & $(-0.99)$ \\
\hline \multirow{2}{*}{ Math/Science grades } & - & - & .10 & .12 \\
\hline & - & - & $(1.82)$ & $(2.02)$ \\
\hline \multirow{2}{*}{ English Grades } & - & - & .44 & .43 \\
\hline & - & - & $(8.7)$ & $(8.46)$ \\
\hline $\mathrm{R}^{2}$ & .04 & .15 & .36 & .41 \\
\hline
\end{tabular}

The results in Tables 7-9 show very different patterns affecting completions at 2-year and 4-year colleges. At the former, when considering only the AA degree, completion rates are higher for females than males but lower among blacks. Interestingly, SES appears to have negative effects on completion at this stage. Achievement accounts for little of the gap in completion across these groups. Including certificates among the credentials completed improves relative results among blacks but otherwise does not change the overall pattern of results.

In contrast, estimated regression equations in Table 9 for the BA degree show stronger negative effects for minorities and positive effects of SES; in fact, the latter help to account for the negative effects of minority status on completion. Achievement gaps fully account for the positive effects observed for females and any remaining negative effect for blacks, which actually becomes positive after controlling for achievement; in other words, blacks have higher completion rates than whites controlling for achievement, while Hispanics have comparable rates controlling for achievement and family SES. Thus, both family income and achievement gaps are quite important in explaining the observed racial and gender gaps in completion of 4-year degrees. 
Finally, in Table 10 we present the results of regression equations for annual (part A) and hourly (part B) earnings respectively. The specifications presented begin with race/gender and SES as explanatory variables, and then include controls for educational attainment and achievement, fields of study (interacted with education) and children under 6 at home, and hours worked per week in successive regressions. 
TABLE 10(A) - Regression Results: Annual Earnings

\begin{tabular}{|c|c|c|c|c|c|}
\hline \multicolumn{6}{|l|}{ Demographic Characteristics } \\
\hline \multirow[t]{2}{*}{ Female } & -0.40 & -0.39 & -0.42 & -0.39 & -0.18 \\
\hline & $(-13.13)$ & $(-12.82)$ & $(-11.05)$ & $(-10.49)$ & $(-6.09)$ \\
\hline \multirow[t]{2}{*}{ Black } & -0.15 & -0.10 & -0.06 & -0.05 & -0.02 \\
\hline & $(-2.12)$ & $(-1.37)$ & $(-0.89)$ & $(-0.74)$ & $(-0.24)$ \\
\hline \multirow{2}{*}{ Hispanic } & -0.13 & -0.05 & -0.05 & -0.04 & 0.00 \\
\hline & $(-2.88)$ & $(-1.03)$ & $(-0.97)$ & $(-0.7)$ & $(-0.11)$ \\
\hline \multirow[t]{2}{*}{ SES } & - & 0.12 & 0.00 & 0.00 & 0.01 \\
\hline & - & $(5.23)$ & $(0.01)$ & $(0.02)$ & $(0.66)$ \\
\hline \multicolumn{6}{|l|}{$\begin{array}{l}\text { High School Achievement } \\
\text { (Grades \& Standardized Scores) }\end{array}$} \\
\hline \multirow[t]{2}{*}{ Math Score } & - & - & 0.01 & 0.01 & 0.01 \\
\hline & - & - & $(3.54)$ & $(3.27)$ & $(3.57)$ \\
\hline \multirow[t]{2}{*}{ Reading Score } & - & - & 0.00 & 0.00 & 0.00 \\
\hline & - & - & $(-1.5)$ & $(-1.03)$ & $(-0.58)$ \\
\hline \multirow[t]{2}{*}{ Math/Science Grades } & - & - & -0.02 & -0.02 & -0.01 \\
\hline & - & - & $(-1.48)$ & $(-1.46)$ & $(-0.85)$ \\
\hline \multirow[t]{2}{*}{ English Grades } & - & - & 0.01 & 0.01 & 0.01 \\
\hline & - & - & $(0.73)$ & $(0.80)$ & $(0.61)$ \\
\hline \multicolumn{6}{|l|}{ Educational Attainment } \\
\hline \multirow[t]{2}{*}{ HS Diploma Only } & - & - & 0.08 & 0.06 & -0.01 \\
\hline & - & - & $(0.58)$ & $(0.47)$ & $(-0.12)$ \\
\hline \multirow[t]{2}{*}{ Attended 2 year College; No Credential } & - & - & 0.15 & 0.11 & 0.03 \\
\hline & - & - & $(1.25)$ & $(0.92)$ & $(0.32)$ \\
\hline \multirow[t]{2}{*}{ Certificate } & - & - & 0.28 & 0.18 & 0.10 \\
\hline & - & - & $(2.22)$ & $(1.21)$ & $(0.72)$ \\
\hline \multirow{2}{*}{$\mathrm{AA}$} & - & - & 0.18 & 0.17 & 0.02 \\
\hline & - & - & $(1.46)$ & $(1.13)$ & $(0.13)$ \\
\hline \multirow{2}{*}{$\begin{array}{l}\text { Attended } 4 \text { Year College; } \\
\text { No Credential }\end{array}$} & - & - & 0.21 & 0.18 & 0.09 \\
\hline & - & - & $(1.74)$ & $(1.50)$ & $(0.89)$ \\
\hline \multirow{2}{*}{ BA } & - & - & 0.43 & 0.39 & 0.18 \\
\hline & - & - & $(3.80)$ & $(3.21)$ & $(1.69)$ \\
\hline \multirow{2}{*}{ MA } & - & - & 0.62 & 0.53 & 0.35 \\
\hline & - & - & $(5.12)$ & $(4.11)$ & $(3.01)$ \\
\hline \multirow{2}{*}{ Advanced } & - & - & 0.77 & 0.70 & 0.34 \\
\hline & - & - & $(2.28)$ & $(2.06)$ & $(1.13)$ \\
\hline \multicolumn{6}{|l|}{ Other } \\
\hline \multirow{2}{*}{ Field of study* degree interactions } & - & - & - & \multirow{2}{*}{ Yes } & \multirow{2}{*}{ Yes } \\
\hline & - & - & - & & \\
\hline \multirow{2}{*}{ Child under 6} & - & - & - & -0.15 & -0.07 \\
\hline & - & - & - & $(-2.37)$ & $(-1.17)$ \\
\hline \multirow{2}{*}{ Hours work per week } & - & - & - & - & 0.02 \\
\hline & - & - & - & - & $(16.17)$ \\
\hline $\mathrm{R}^{2}$ & 0.05 & 0.06 & 0.08 & 0.10 & 0.26 \\
\hline
\end{tabular}




\begin{tabular}{|c|c|c|c|c|c|}
\hline \multicolumn{6}{|c|}{ TABLE 10(B) - Regression Results: Hourly Earnings } \\
\hline \multicolumn{6}{|l|}{ Demographic Characteristics } \\
\hline \multirow[t]{2}{*}{ Female } & -0.19 & -0.18 & -0.20 & -0.18 & -0.15 \\
\hline & $(11.69)$ & $(11.07)$ & $(11.16)$ & $(10.33)$ & $(8.43)$ \\
\hline \multirow[t]{2}{*}{ Black } & -0.11 & -0.06 & -0.01 & -0.01 & 0.00 \\
\hline & $(3.62)$ & $(2.11)$ & $(0.44)$ & $(0.33)$ & $(0.12)$ \\
\hline \multirow[t]{2}{*}{ Hispanic } & -0.07 & 0.01 & 0.02 & 0.03 & 0.04 \\
\hline & $(2.84)$ & $(0.36)$ & $(0.88)$ & $(1.31)$ & $(1.59)$ \\
\hline \multirow[t]{2}{*}{ SES } & - & 0.12 & 0.03 & 0.03 & 0.03 \\
\hline & - & $(9.25)$ & $(2.50)$ & $(2.56)$ & $(2.84)$ \\
\hline \multicolumn{6}{|l|}{$\begin{array}{l}\text { High School Achievement } \\
\text { (Grades \& Standardized Scores) }\end{array}$} \\
\hline \multirow[t]{2}{*}{ Math Score } & - & - & 0.01 & 0.01 & 0.01 \\
\hline & - & - & $(6.52)$ & $(6.29)$ & $(6.29)$ \\
\hline \multirow[t]{2}{*}{ Reading Score } & - & - & 0.00 & 0.00 & 0.00 \\
\hline & - & - & $(2.57)$ & $(2.23)$ & (2.11) \\
\hline \multirow[t]{2}{*}{ Math/Science Grades } & - & - & -0.01 & -0.01 & -0.01 \\
\hline & - & - & $(2.44)$ & $(2.62)$ & $(2.41)$ \\
\hline \multirow[t]{2}{*}{ English Grades } & - & - & 0.01 & 0.01 & 0.01 \\
\hline & - & - & - & $(1.96)$ & $(1.91)$ \\
\hline \multicolumn{6}{|l|}{ Educational Attainment } \\
\hline \multirow[t]{2}{*}{ HS Diploma Only } & - & - & -0.06 & -0.06 & -0.07 \\
\hline & - & - & $(1.10)$ & $(1.21)$ & $(1.51)$ \\
\hline \multirow[t]{2}{*}{ Attended 2 year College; No Credential } & - & - & -0.04 & -0.06 & -0.07 \\
\hline & - & - & $(0.90)$ & $(1.23)$ & $(1.53)$ \\
\hline \multirow[t]{2}{*}{ Certificate } & - & - & 0.05 & -0.04 & -0.05 \\
\hline & - & - & $(0.83)$ & $(0.71)$ & $(0.95)$ \\
\hline \multirow{2}{*}{ AA } & - & - & 0.06 & -0.05 & -0.07 \\
\hline & - & - & $(1.20)$ & $(0.70)$ & $(1.07)$ \\
\hline \multirow{2}{*}{$\begin{array}{l}\text { Attended } 4 \text { Year College; } \\
\text { No Credential }\end{array}$} & - & - & 0.00 & -0.01 & -0.02 \\
\hline & - & - & $(0.08)$ & $(0.18)$ & $(0.46)$ \\
\hline \multirow{2}{*}{$\mathrm{BA}$} & - & - & 0.16 & 0.10 & 0.07 \\
\hline & - & - & $(3.39)$ & $(1.74)$ & $(1.20)$ \\
\hline \multirow{2}{*}{ MA } & - & - & 0.37 & 0.29 & 0.27 \\
\hline & - & - & $(6.61)$ & $(4.41)$ & $(3.99)$ \\
\hline \multirow{2}{*}{ Advanced } & - & - & 0.56 & 0.51 & 0.45 \\
\hline & - & - & $(6.06)$ & $(5.58)$ & $(4.79)$ \\
\hline \multicolumn{6}{|l|}{ Other } \\
\hline \multirow{2}{*}{ Field of study* degree interactions } & - & - & - & \multirow{2}{*}{ Yes } & \multirow{2}{*}{ Yes } \\
\hline & - & - & - & & \\
\hline Child under 6 & - & - & - & -0.07 & -0.05 \\
\hline Child under 6 & - & - & - & $(2.48)$ & (2.01) \\
\hline Hours work ner week & - & - & - & - & 0.00 \\
\hline Hours work per week & - & - & - & - & (7.38) \\
\hline $\mathrm{R}^{2}$ & 0.05 & 0.08 & 0.15 & 0.18 & 0.20 \\
\hline
\end{tabular}


The results show large earnings gaps between men and women, despite the better educational attainment and achievement among the latter; and smaller ones between minorities and whites, while SES has positive effects. Controlling for education and achievement has very little effect on the gender gap in earnings but tends to narrow the gaps between whites and minorities and between SES groups considerably. Controlling for field of study by educational attainment and for presence of small children in the home has very modest effects on the gender gap in earnings; but controlling for hours worked per week accounts for half of the annual earnings difference and also a smaller part of the hourly earnings difference between young men and women. ${ }^{7}$

Among the educational credentials, it is noteworthy that certificates have quite positive effects on earnings, relative to those with "some college" or AA degrees. This strengthens our earlier findings that certificate attainment can have positive impacts both on employment and hourly earnings for those with only high school or less education.

\section{Consistency With Broader Research Literature}

Many of the findings presented above are not dramatically new, and are broadly consistent with the extant research literature. For instance, achievement gaps by race, gender and income group have been widely explored elsewhere (Magnuson and Waldfogel, 2008; Reardon, 2011;

Cornwell et al., 2009). Gaps in educational attainment across these groups and their trends over time have also been explored at great length (e.g., Heckman and Lafontaine, 2007; Bailey and Dynarski, 2011).

Indeed, Reardon and Bailey and Dynarski suggest that achievement and attainment gaps by family income might be rising over time, consistent with the large gaps estimated above. Magnuson and Waldfogel show that racial gaps in achievement have declined only modestly over time, also consistent with the large gaps that remain. Gaps in college completion rates across racial and family income groups have been also documented and explored (Haskins et al., 2009; Bound et al., 2009; Complete College America, 2011). In this literature, it is clear that gaps in college attainment and completion across family income groups persist, even controlling for achievement.

But, in contrast to Waldfogel (1998), who suggested that gender gaps had largely disappeared in the 1990s among the youngest cohort of workers and before childrearing began for women, we find quite significant earnings gaps favoring young men over women in both sets of data, and despite the higher levels of postsecondary education and achievement among females. The tendency of young women to work fewer hours per week and per year seems an important contributor to these earnings gaps in our work, with field of study and child care directly contributing somewhat less.

\footnotetext{
${ }^{7}$ We cannot control for years of experience or job tenure in these equations, which often has important effects in accounting for gender gaps in earnings; though, for such a young cohort, the effects in this case would likely be more modest.
} 
Also, Altonji et al. (2012) review the literature on fields of study, and its effects on earnings. They stress that fields of study in college and beyond are shaped by individual preferences and academic choices made much earlier and under great uncertainty for individuals. Our work suggests large differences by gender in these choices, in ways that might well be shaped by the preferences and earlier choices emphasized by Altonji and his coauthors, and perhaps also by limited information on returns when these choices are made.

Regarding labor market outcomes and their relationship to postsecondary education, Goldin and Katz (2008) have shown quite convincingly that rising inequality in the labor market has been caused by a failure of the supply of higher education to keep pace with rising labor market demand for such education since the 1970s. ${ }^{8}$ The large extent to which achievement and education gaps account for earnings gaps across race has been explored by Neal (2006); but recent work by Heckman et al. (2006), among others, suggests that cognitive achievement as measured by test scores accounts for somewhat less inequality than is often believed to be true. And, while economists continue to explore the extent to which the effects of education on earnings are truly causal, the recent evidence has certainly suggested that they are (Card, 1999).

Some attention has also been paid recently to sub-BA attainment, and its effects on labor market outcomes, with findings that are broadly consistent with ours. For instance, Marcotte (2006) shows relatively strong returns to AA attainment, while Carnevale et al. (2012) does so with certificates, though in both cases there is great variation in these returns across fields of concentration. Using state-level administrative data, other studies have also shown the potentially strong labor market returns to at least some of these sub-BA credentials, especially in more technical or high-demand fields (Jacobson and Mokher, 2009; Jepsen et al, 2009).

The estimated returns to sub-BA credentials also appear to run somewhat counter to the popularized notion of a disappearing "middle" of the job market. Indeed, recent estimates of a shrinking middle are heavily driven by the large declines in good-paying production and clerical jobs since 1980, especially among high school graduates. A new middle of the job market has emerged that now requires a greater performance of cognitive tasks, and usually somewhat more postsecondary education or training, than was earlier the case (Holzer, 2012). ${ }^{9}$

While many of our findings confirm what has been found in this literature, we add some new wrinkles and extensions. For instance, the trends in school attainments since 2000 have not been explored at great length. Our findings of rising attainment of sub-BA credentials, especially by minorities, is noteworthy, as well as our finding that gaps may have widened during the Great

\footnotetext{
${ }^{8}$ The debate between more mainstream labor economists and "revisionists" on the extent to which market forces drive returns to education, as opposed to institutional factors, remains strong. See Autor et al. (2008) and Card and Dinardo (2007).

${ }^{9}$ See Autor (2010) and Holzer (2010) for views with somewhat different emphases on this topic, though Acemoglu and Autor (2012) clearly acknowledge the importance of sub-BA educational attainment in their work. Whether further declines in middle-wage jobs that occurred during the Great Recession are permanent (as argued by Jaimovich and Siu, 2012) or not remains unclear.
} 
Recession. Our findings of relatively comparable (though uniformly low) rates of sub-BA credentials across racial and income groups, but much larger gaps at the BA level, is fairly new as well. Finally, our analysis of ongoing gaps in achievement by race/gender and family income, and the extent to which these contribute to differences in postsecondary education, field of study and labor market outcomes, is more complete and up-to-date than most others in the literature.

\section{Conclusion}

In this paper, we investigate the basic empirical facts on gaps in postsecondary and labor market outcomes between disadvantaged students (defined as minority students or those from lowincome families) and other students, and how they have trended over time. We present mostly summary results from the SIPP data and also from the NELS cohort of 1988, and use them to generate a comprehensive and up-to-date portrait of recent trends in education and earnings outcomes as well as remaining gaps between groups (defined by race/gender and family background). Our hope is that these findings can serve as the basis for further research, especially using new administrative datasets on education and earnings that are rapidly becoming available at the state level.

With the SIPP data, we present results on:

- Educational attainment by year - Overall and by race/gender;

- Fields of study for those with certificates, AA, BA and advanced degrees - By race/gender in 2010;

- Employment rates and mean hourly wages by educational attainment Overall and by race/gender in 2010; and

- Employment rates and mean hourly wages by field of study for those with certificates, AA, BA and advanced degrees in 2010.

We then present findings on educational attainment and employment outcomes using the NELS data. Since the latter have much richer data on measures of academic achievement in high school, we provide more evidence of these outcomes, and how they correlate with race/gender and family SES of students. We also briefly explore the extent to which some observed gaps across groups in educational attainment and earnings can be accounted for by our measures of achievement and (for earnings) educational attainment.

Our findings can be summarized as follows:

1. Educational attainment has risen modestly among young adults in the past two decades, with gains in BA attainment in the 1990s and more in certificate and AA attainment since 2000. Improvements are even stronger among the broader age group, some of which might be attributable to the changing composition of the sample (as less-educated older 
workers age out of the group). But increases in the percentages of all workers holding certificates and AAs over time seem too large to be attributable only to compositional changes, implying that older workers as well as younger ones are gaining more of these credentials over time.

2. Postsecondary educational attainment has risen in response to the Great Recession. Among young adults, achievement of BAs and MAs seem to have been most responsive to the downturn, while among older adults gains in certificates are noteworthy.

3. Race and gender gaps in educational attainment remain strong. The gender gap favoring women over men can be found in all racial groups and is much more pronounced among the younger cohort than among others. Blacks and Hispanics have made more relative progress in the attainment of certificates and AAs than in BAs or above, among older as well as younger cohorts.

4. Completion rates at 2-year colleges are much lower on average than at 4-year schools, but large gaps by race, income and achievement persist at the latter. The 2-year completion rates are particularly low if we do not count certificate attainment. Most groups have low completion rates at the 2-year level. But completion rates are particularly low at the 4-year colleges for minorities, low-income students and low achievers.

5. Achievement gaps by race, gender, and family background contribute to the gaps in postsecondary attainment across these groups. We consistently find minorities and those from the lowest SES quartile obtaining lower grades and test scores than other students. Females generally score higher than males, though less so in math/science. Those with higher grades in particular areas also tend to take more courses in them.

6. Those with higher achievement earn higher educational credentials and are more likely to concentrate in the fields that are well-compensated. Thus those from above the bottom quartile of family SES obtain higher educational credentials and are more concentrated in well-compensated fields (like engineering/technical) than those from poorer families. On the other hand, males tend to concentrate in the well-compensated fields of study relative to females, despite higher K-12 achievement among the latter.

7. Gender gaps also persist in fields of study among those obtaining any particular certification. Males are more likely than females to obtain certification in engineering or technical fields; women are more likely to do so in health and education. Women also are more likely to obtain certificates or AAs in business than men, while men are more likely to obtain BAs in business and MBAs.

8. There appear to be returns (in terms of higher employment and wages) to the attainment of all certifications, including certificates and AAs, for all groups. In particular, holders of certificates have better employment outcomes than high school graduates, though generally less than those with some college and considerably less than those with AAs or BAs. 
9. Labor market returns also vary by field of study. Those in technical areas generally earn higher wages relative to other fields. Those in health earn relatively high wages at the AA level and above, while those in business do so at the BA and above. Thus, returns to field are generally higher in areas where males (and, to some extent, whites) are relatively more concentrated.

10. High school achievement explains much (though not all) of the gender and race gaps we find in BA attainment and race gaps in annual earnings. But the gender gap in annual earnings cannot be explained by high school achievement, educational attainment, or field of study.

Though many of these findings have been observed before in the research literature, we believe this is the most up-to-date and comprehensive summary of the basic facts on postsecondary education and labor market outcomes - including the most recent trends over time and remaining gaps across race/gender and family background groups - that has been presented to date. Our findings of rising attainment of sub-BA degrees among minorities and of BA and above by whites, as well as ongoing gaps in completion rates among students at the BA level, are particularly noteworthy.

We also believe that these findings have implications both for further research and policy. For instance, the ongoing achievement and postsecondary attainment gaps by race and by SES clearly need further understanding. They also imply that policies to reduce such gaps at the postsecondary level and earlier should remain a high priority. The former might include different forms of financial aid (e.g., Dunlop, 2013) and academic remediation, as well as newer forms of "affirmative action" in admissions (Antonovics and Backes, 2013) that take into account socioeconomic status as well as race. Further understanding of the puzzling gender gap in earnings favoring males, despite the gap favoring females in achievement and education, also should remain high on the research agenda.

The continuing labor market gains for those with sub-BA degrees and certificates, relative to a high school diploma, suggest that we have not yet reached the point of greatly diminishing returns to these credentials. Given the relatively low rates of credential completion in community colleges for all groups, policies to improve completion at this stage would remain welcome. But, in addition, it seems very unlikely that choices of field of study at both 2-year and 4-year institutions are fully informed by the facts when they are made. Accordingly, better labor market information on returns to different fields should probably be made available at the postsecondary level, and earlier as well. Career counseling should also probably be improved at all stages of education. And, in addition to improving the information about the labor market available to students, perhaps policies that provide stronger incentives for institutions to raise completion rates, both overall and in fields with strong labor market demand, should be considered as well (Jacobson and Mokher, 2009). 


\section{REFERENCES}

Acemoglu, Daron and David Autor. 2012. "What Does Human Capital Do? A Review of Goldin and Katz' Book The Race Between Education and Technology." Journal of Economic Literature, 50(2), 426-63.

Altonji Jopseh; E. Bloom and C. Meghir. 2012. "Heterogeneity in Human Capital Investments: High School Curriculum, College Major and Careers.” NBER Working Paper No. 17985 .

Antonovics, Kate and Ben Backes. "Color-Blind Affirmative Action and Student Quality.” Working Paper, CALDER, American Institutes for Research.

Autor, David. 2010. "The Polarization of Job Market Opportunities in the US.”Center for American Progress, Washington DC.

Autor David; Lawrence Katz and Melissa Kearney. 2008. "The Polarization of the U.S. Labor Market.” National Bureau of Economic Research (NBER) Working Paper.

Bailey, Martha and Susan Dynarski. 2011."Inequality in Postsecondary Attainment.” In G. Duncan and R. Murnane eds. Whither Opportunity? Rising Inequality, Schools, and Children's Life Chances. New York: Russell Sage Foundation.

Bound, John; Michael Lovenheim and Sarah Turner. 2009. "Why Have College Completion Rates Declined? An Analysis of Changing Student Preparation and Collegiate Resources.” NBER Working Paper 15566.

Brown, Charles and Mary Corcoran. 1996. "Sex-Based Differences in School Content and the Male/Female Wage Gap." 1996. NBER Working Paper.

Card, David. 1999. "The Causal Effect of Education on Earnings. " In O. Ashenfelter and D. Card Eds. The Handbook of Labor Economics, Vol. 3A. Amsterdam: North Holland.

Card, David and Jonathan DiNardo. "The Impact of Technological Change on LowWage Workers: A Review.” In R. Blank, S. Danziger and R. Schoeni eds. Working and Poor: How Economic and Policy Changes are Affecting Low-Wage Workers. New York: Russell Sage Foundation.

Carnevale, Anthony;Stephen Rose and Andrew Hanson. 2012. "Certificates: Gateway to GainfulEmployment and College Degrees." Washington DC: Georgetown Center on Education and the Workforce.

Complete College America. 2012. Time is the Enemy: The Surprising Truth About Why Today's College Students Aren't Graduating... and What Can Be Done About It. Washington DC: 
National Governors’ Association.

Cornwell, Christopher; David Mustard and Jessica Van Parys. 2009. "Non-cognitive Skills and the Gender Disparities in Test Scores and Teacher Assessments: Evidencefrom Primary School.” IZA Discussion Paper.

Dunlop, Erin. 2013. "What Do Stafford Loans Actually Buy You? - The Effect of Stafford Loan Access on Community College Students.” Working Paper, American Institutes for Research/CALDER.

Goldin, Claudia and Lawrence Katz. 2008. The Race Between Education and Technology. Cambridge MA: Harvard University Press.

Haskins Ron; Harry Holzer and Robert Lerman. 2009. Promoting Economic Mobility by Increasing Postsecondary Education. Economic Mobility Project, Pew Charitable Trusts, Washington DC.

Heckman James; and Paul Lafontaine.2007 “The American High School Graduation Rate: Trends and Levels.” NBER Working Paper.

Heckman, James; Jora Stixrud and Sergio Urzua. 2006. "The Effects of Cognitive and Noncognitive Abilities on Labor Market Outcomes and Social Behavior." NBER Working Paper.

Holzer, Harry J. 2012. "Good Workers for Good Jobs: Improving Education and Workforce Systems in the US.” IZA Journal of Labor Policy, Vol. 1.

Holzer, Harry J. 2010. "Is the Middle of the Labor Market Disappearing? Comments on the Polarization Hypothesis.” Center for American Progress, Washington DC.

Jacobson Lou and Christine Mokher 2009. Pathways to Boosting the Earnings of LowIncome Workers. CNA, Washington DC.

Jaimovich, Nir and Henry Siu. 2012. "The Trend is the Cycle: Job Polarization and Jobless Recoveries.” NBER Working Paper.

Jepsen, Christopher; Kenneth Troske and Paul Coomes. 2009. "The Labor Market Returns to Community College Degrees, Diplomas, and Certificates.” Discussion Paper, Center for Poverty Research, University of Kentucky.

Magnuson, Katharine and Jane Waldfogel eds. 2008. Steady Gains and Stalled PRogerss: Inequality and the Black-White Test Score Gap. New York: Russell Sage Foundation.

Marcotte, David. 2006. "The Earnings Effect of Education at Community Colleges.” IZA Discussion Paper. 
Neal, Derek. 2006. "Why Has Black-White Skill Convergence Stopped?” NBER Working Paper.

Reardon, Sean. 2011. "The Widening Academic Achievement Gap Between the Rich and the Poor: New Evidence and Possible Explanations." In G. Duncan and R. Murnane eds. Whither Opportunity? Rising Inequality, Schools, and Children's Life Chances. New York: Russell Sage Foundation.

Turner, Sarah. 2007. "Higher Education Policies Generating the $21^{\text {st }}$ Century Workforce." In H. Holzer and D. Nightingale eds. Reshaping the American Workforce in a Changing Economy. Washington DC: Urban Institute Press.

Waldfogel, Jane. 1998. "The Family Gap for Young Women in the United States and Great Britain: Can Maternity Leave Make a Difference?” Journal of Labor Economics. Vol . 16, No. 2 


\section{APPENDIX}

\begin{tabular}{|l|c|c|c|c|}
\hline \multicolumn{5}{|c|}{ Table A1(A) - Educational Attainment } \\
\hline Degree & 1990 & 2001 & 2007 & 2010 \\
\hline Dropout & .17 & .14 & .10 & .11 \\
GED & - & .06 & .05 & .04 \\
High School Graduate & .36 & .26 & .20 & .20 \\
Some College & .17 & .18 & .17 & .14 \\
Certificate & .03 & .04 & .09 & .11 \\
Associates & .05 & .04 & .09 & .09 \\
Bachelors & .15 & .19 & .19 & .20 \\
Masters & .05 & .07 & .07 & .08 \\
Professional & .01 & .02 & .02 & .02 \\
Doctorate & .01 & .01 & .01 & .01 \\
\hline Sample N & 112043 & 135563 & 72379 & 150086 \\
\hline
\end{tabular}

Note: (1) The information presented on this table is based on sample-weighted data. (2) Subjects were excluded from the sample if their age was below 25 or above 69 , their hourly income was below $\$ 3$ or above $\$ 100$, were only on either the core file or topical module but not on both or were not interviewed in the reference month. (3) Due to survey design constraints, GED holders are categorized as HS Grads in the 1990 data; whereas in the 2000s tables they are categorized separately. 


\begin{tabular}{|c|c|c|c|c|c|c|}
\hline \multicolumn{7}{|c|}{ Table A1(B) - Educational Attainment by Race/Gender } \\
\hline Race & Gender & Education & 1990 & 2001 & 2007 & 2010 \\
\hline \multirow{11}{*}{ Black } & \multirow{11}{*}{ Males } & Dropout & .29 & .18 & .09 & .12 \\
\hline & & GED & - & .09 & .06 & .05 \\
\hline & & High School Graduate & .39 & .30 & .27 & .25 \\
\hline & & Some College & .17 & .20 & .21 & .17 \\
\hline & & Certificate & .01 & .04 & .13 & .15 \\
\hline & & Associates & .03 & .04 & .05 & .08 \\
\hline & & Bachelors & .08 & .10 & .12 & .12 \\
\hline & & Masters & .03 & .04 & .05 & .04 \\
\hline & & Professional & .01 & .01 & .01 & .01 \\
\hline & & Doctorate & .00 & .01 & .01 & .01 \\
\hline & & Sample N & 5015 & 6657 & 3189 & 6534 \\
\hline \multirow{11}{*}{ Black } & \multirow{11}{*}{ Females } & Dropout & .27 & .19 & .12 & .12 \\
\hline & & GED & - & .06 & .05 & .03 \\
\hline & & High School Graduate & .36 & .27 & .23 & .20 \\
\hline & & Some College & .20 & .21 & .20 & .16 \\
\hline & & Certificate & .02 & .04 & .14 & .17 \\
\hline & & Associates & .04 & .04 & .08 & .10 \\
\hline & & Bachelors & .08 & .12 & .12 & .15 \\
\hline & & Masters & .03 & .05 & .06 & .05 \\
\hline & & Professional & .00 & .01 & .01 & .01 \\
\hline & & Doctorate & .00 & .00 & .00 & .01 \\
\hline & & Sample N & 7260 & 9097 & 4715 & 9396 \\
\hline \multirow{11}{*}{ Hispanic } & \multirow{11}{*}{ Males } & Dropout & .44 & .46 & .34 & .35 \\
\hline & & GED & - & .05 & .11 & .06 \\
\hline & & High School Graduate & .28 & .20 & .18 & .21 \\
\hline & & Some College & .14 & .14 & .13 & .11 \\
\hline & & Certificate & .01 & .02 & .07 & .10 \\
\hline & & Associates & .03 & .02 & .06 & .05 \\
\hline & & Bachelors & .08 & .08 & .07 & .08 \\
\hline & & Masters & .02 & .01 & .02 & .02 \\
\hline & & Professional & .01 & .01 & .00 & .01 \\
\hline & & Doctorate & .00 & .01 & .01 & .01 \\
\hline & & Sample N & 4988 & 6966 & 3473 & 7157 \\
\hline
\end{tabular}




\begin{tabular}{|c|c|c|c|c|c|c|}
\hline \multirow{11}{*}{ Hispanic } & \multirow{11}{*}{ Females } & Dropout & .44 & .43 & .36 & .35 \\
\hline & & GED & - & .06 & .08 & .05 \\
\hline & & High School Graduate & .29 & .2 & .17 & .19 \\
\hline & & Some College & .13 & .14 & .12 & .11 \\
\hline & & Certificate & .02 & .03 & .08 & .10 \\
\hline & & Associates & .03 & .03 & .08 & .07 \\
\hline & & Bachelors & .06 & .08 & .09 & .10 \\
\hline & & Masters & .02 & .02 & .01 & .03 \\
\hline & & Professional & .00 & .01 & .01 & .00 \\
\hline & & Doctorate & .00 & .00 & .00 & .00 \\
\hline & & Sample N & 5820 & 7510 & 3958 & 8358 \\
\hline \multirow{11}{*}{ Whites } & \multirow{11}{*}{ Males } & Dropout & .14 & .09 & .06 & .06 \\
\hline & & GED & - & .06 & .05 & .04 \\
\hline & & High School Graduate & .34 & .26 & .20 & .20 \\
\hline & & Some College & .17 & .19 & .18 & .14 \\
\hline & & Certificate & .02 & .04 & .09 & .12 \\
\hline & & Associates & .05 & .04 & .09 & .09 \\
\hline & & Bachelors & .17 & .21 & .22 & .23 \\
\hline & & Masters & .06 & .08 & .08 & .09 \\
\hline & & Professional & .02 & .02 & .03 & .02 \\
\hline & & Doctorate & .01 & .02 & .02 & .02 \\
\hline & & Sample N & 40540 & 48158 & 24470 & 51399 \\
\hline \multirow{11}{*}{ Whites } & \multirow{11}{*}{ Females } & Dropout & .14 & .08 & .05 & .05 \\
\hline & & GED & - & .05 & .04 & .03 \\
\hline & & High School Graduate & .39 & .27 & .20 & .19 \\
\hline & & Some College & .17 & .20 & .18 & .15 \\
\hline & & Certificate & .04 & .05 & .08 & .11 \\
\hline & & Associates & .05 & .05 & .11 & .11 \\
\hline & & Bachelors & .14 & .20 & .23 & .23 \\
\hline & & Masters & .05 & .08 & .09 & .10 \\
\hline & & Professional & .01 & .01 & .01 & .02 \\
\hline & & Doctorate & .00 & .01 & .01 & .01 \\
\hline & & Sample N & 44534 & 50321 & 27363 & 55807 \\
\hline
\end{tabular}




\begin{tabular}{|c|c|c|c|c|c|c|}
\hline \multicolumn{7}{|c|}{$\begin{array}{c}\text { Table A2 - Distribution of People Across Field of Study } \\
\text { by Race and Gender in } 2010\end{array}$} \\
\hline \multirow[b]{2}{*}{ Education } & \multirow[b]{2}{*}{ Field } & \multicolumn{2}{|c|}{ Gender } & \multicolumn{3}{|c|}{ Race } \\
\hline & & Males & Females & Blacks & Hispanic & Whites \\
\hline \multirow{5}{*}{ Certificate } & Business & 0.05 & 0.20 & 0.14 & 0.15 & 0.12 \\
\hline & Engineering/Technical & 0.55 & 0.08 & 0.26 & 0.30 & 0.32 \\
\hline & Health & 0.05 & 0.27 & 0.22 & 0.17 & 0.15 \\
\hline & Other & 0.35 & 0.45 & 0.38 & 0.39 & 0.41 \\
\hline & Sample N & 8374 & 9245 & 2581 & 1528 & 12307 \\
\hline \multirow{10}{*}{ Associates } & Arts/Humanities & 0.08 & 0.10 & 0.11 & 0.08 & 0.09 \\
\hline & Business & 0.16 & 0.23 & 0.20 & 0.22 & 0.20 \\
\hline & Communications & 0.02 & 0.01 & 0.01 & 0.01 & 0.01 \\
\hline & Education & 0.02 & 0.06 & 0.06 & 0.07 & 0.03 \\
\hline & Engineering/Technical & 0.36 & 0.09 & 0.21 & 0.22 & 0.20 \\
\hline & Health & 0.08 & 0.24 & 0.17 & 0.12 & 0.18 \\
\hline & Natural Sciences & 0.02 & 0.02 & 0.02 & 0.01 & 0.02 \\
\hline & Other & 0.25 & 0.23 & 0.19 & 0.25 & 0.24 \\
\hline & Social Sciences & 0.02 & 0.02 & 0.03 & 0.02 & 0.02 \\
\hline & Sample N & 5814 & 7962 & 1389 & 855 & 10667 \\
\hline \multirow{10}{*}{ Bachelors } & Arts/Humanities & 0.10 & 0.14 & 0.10 & 0.12 & 0.13 \\
\hline & Business & 0.24 & 0.19 & 0.28 & 0.25 & 0.20 \\
\hline & Communications & 0.04 & 0.04 & 0.04 & 0.04 & 0.04 \\
\hline & Education & 0.05 & 0.17 & 0.11 & 0.15 & 0.12 \\
\hline & Engineering/Technical & 0.23 & 0.04 & 0.12 & 0.13 & 0.12 \\
\hline & Health & 0.02 & 0.09 & 0.05 & 0.04 & 0.05 \\
\hline & Natural Sciences & 0.07 & 0.06 & 0.05 & 0.04 & 0.06 \\
\hline & Other & 0.18 & 0.18 & 0.15 & 0.16 & 0.18 \\
\hline & Social Sciences & 0.07 & 0.11 & 0.11 & 0.08 & 0.09 \\
\hline & Sample N & 13869 & 15893 & 2012 & 1282 & 23681 \\
\hline \multirow{11}{*}{ Advanced } & Arts/Humanities & 0.08 & 0.07 & 0.07 & 0.05 & 0.08 \\
\hline & Business & 0.19 & 0.11 & 0.21 & 0.15 & 0.15 \\
\hline & Communications & 0.01 & 0.01 & 0.02 & 0.02 & 0.01 \\
\hline & Education & 0.13 & 0.32 & 0.23 & 0.28 & 0.24 \\
\hline & Engineering/Technical & 0.16 & 0.05 & 0.08 & 0.13 & 0.09 \\
\hline & Health & 0.10 & 0.12 & 0.10 & 0.10 & 0.10 \\
\hline & Law & 0.10 & 0.07 & 0.11 & 0.10 & 0.09 \\
\hline & Natural Sciences & 0.06 & 0.05 & 0.02 & 0.05 & 0.05 \\
\hline & Other & 0.17 & 0.19 & 0.16 & 0.11 & 0.19 \\
\hline & Social Sciences & & & & & \\
\hline & Sample N & 7429 & 7630 & 923 & 437 & 12176 \\
\hline
\end{tabular}




\begin{tabular}{|c|c|c|c|c|c|}
\hline \multicolumn{6}{|c|}{$\begin{array}{l}\text { Table A3 - Employment Rate and Mean Hourly Wages } \\
\text { by Education by Race/Gender in } 2010\end{array}$} \\
\hline Education & Race & Gender & Employment Rate & $\mathrm{N}$ & $\begin{array}{l}\text { Mean Hourly Wage } \\
\text { (in } 2010 \$)\end{array}$ \\
\hline \multirow{6}{*}{ Dropout } & \multirow{2}{*}{ Black } & Male & 0.44 & 934 & $\$ 12.91$ \\
\hline & & Female & 0.35 & 1325 & $\$ 10.78$ \\
\hline & \multirow{2}{*}{ Hispanic } & Male & 0.78 & 2719 & $\$ 13.44$ \\
\hline & & Female & 0.43 & 3130 & $\$ 9.90$ \\
\hline & \multirow{2}{*}{ White } & Male & 0.60 & 3490 & $\$ 15.24$ \\
\hline & & Female & 0.41 & 3273 & $\$ 12.53$ \\
\hline \multirow{6}{*}{ GED } & \multirow{2}{*}{ Black } & Male & 0.64 & 313 & $\$ 14.42$ \\
\hline & & Female & 0.53 & 363 & $\$ 15.11$ \\
\hline & \multirow{2}{*}{ Hispanic } & Male & 0.71 & 437 & $\$ 15.56$ \\
\hline & & Female & 0.52 & 458 & $\$ 11.27$ \\
\hline & \multirow{2}{*}{ White } & Male & 0.64 & 2005 & $\$ 17.79$ \\
\hline & & Female & 0.52 & 1920 & $\$ 13.63$ \\
\hline \multirow{6}{*}{ High School } & \multirow{2}{*}{ Black } & Male & 0.68 & 1663 & $\$ 15.47$ \\
\hline & & Female & 0.56 & 1965 & $\$ 12.54$ \\
\hline & \multirow{2}{*}{ Hispanic } & Male & 0.80 & 1473 & $\$ 15.81$ \\
\hline & & Female & 0.57 & 1517 & $\$ 13.74$ \\
\hline & \multirow{2}{*}{ White } & Male & 0.75 & 10609 & $\$ 19.01$ \\
\hline & & Female & 0.60 & 11145 & $\$ 15.50$ \\
\hline \multirow{6}{*}{ Some College } & \multirow{2}{*}{ Black } & Male & 0.70 & 970 & $\$ 18.11$ \\
\hline & & Female & 0.73 & 1397 & $\$ 15.33$ \\
\hline & \multirow{2}{*}{ Hispanic } & Male & 0.85 & 743 & $\$ 19.45$ \\
\hline & & Female & 0.68 & 893 & $\$ 14.87$ \\
\hline & \multirow{2}{*}{ White } & Male & 0.82 & 6855 & $\$ 21.46$ \\
\hline & & Female & 0.69 & 8046 & $\$ 17.15$ \\
\hline \multirow{6}{*}{ Certificate } & \multirow{2}{*}{ Black } & Male & 0.62 & 1002 & $\$ 18.11$ \\
\hline & & Female & 0.66 & 1579 & $\$ 14.17$ \\
\hline & \multirow{2}{*}{ Hispanic } & Male & 0.80 & 662 & $\$ 17.96$ \\
\hline & & Female & 0.66 & 866 & $\$ 15.04$ \\
\hline & \multirow{2}{*}{ White } & Male & 0.73 & 6130 & $\$ 21.13$ \\
\hline & & Female & 0.65 & 6177 & $\$ 16.43$ \\
\hline \multirow{6}{*}{ Associates } & \multirow{2}{*}{ Black } & Male & 0.80 & 544 & $\$ 21.21$ \\
\hline & & Female & 0.75 & 845 & $\$ 17.73$ \\
\hline & \multirow{2}{*}{ Hispanic } & Male & 0.80 & 346 & $\$ 22.05$ \\
\hline & & Female & 0.71 & 509 & $\$ 16.90$ \\
\hline & WWhite & Male & 0.82 & 4549 & $\$ 24.28$ \\
\hline & White & Female & 0.75 & 6118 & $\$ 20.08$ \\
\hline & Black & Male & 0.84 & 737 & $\$ 25.64$ \\
\hline & Black & Female & 0.81 & 1275 & $\$ 21.81$ \\
\hline Bachelors & Hisnanic & Male & 0.86 & 544 & $\$ 24.07$ \\
\hline Bachelors & Hispanic & Female & 0.71 & 738 & $\$ 20.88$ \\
\hline & & Male & 0.88 & 11383 & $\$ 30.21$ \\
\hline & White & Female & 0.75 & 12298 & $\$ 23.80$ \\
\hline
\end{tabular}


Table A4 - Employment Rate, Mean Hourly Wages

by Degree/Fields of Study in 2010

\begin{tabular}{|c|c|c|c|c|}
\hline Education & Field & Employment Rate & $\mathrm{N}$ & $\begin{array}{l}\text { Mean Wage } \\
\text { (in } 2010 \$ \text { ) }\end{array}$ \\
\hline \multirow{4}{*}{ Certificate } & Health & 0.69 & 2931 & $\$ 16.29$ \\
\hline & Business & 0.65 & 2184 & $\$ 17.35$ \\
\hline & Engineering/Technical & 0.72 & 5421 & $\$ 19.59$ \\
\hline & Other & 0.66 & 7083 & $\$ 17.80$ \\
\hline \multirow{9}{*}{ Associates } & Health & 0.79 & 2415 & $\$ 22.77$ \\
\hline & Arts/Humanities & 0.75 & 1225 & $\$ 18.47$ \\
\hline & Education & 0.76 & 584 & $\$ 17.40$ \\
\hline & Communications & 0.70 & 170 & $\$ 20.82$ \\
\hline & Business & 0.75 & 2744 & $\$ 20.29$ \\
\hline & Engineering/Technical & 0.79 & 2733 & $\$ 22.86$ \\
\hline & Social Sciences & 0.67 & 302 & $\$ 19.29$ \\
\hline & Natural Sciences/Math & 0.75 & 247 & $\$ 19.54$ \\
\hline & Other & 0.78 & 3356 & $\$ 21.80$ \\
\hline \multirow{9}{*}{ Bachelors } & Health & 0.84 & 1660 & $\$ 27.73$ \\
\hline & Arts/Humanities & 0.77 & 3661 & $\$ 24.09$ \\
\hline & Education & 0.73 & 3442 & $\$ 19.55$ \\
\hline & Communications & 0.90 & 1050 & $\$ 24.48$ \\
\hline & Business & 0.83 & 6306 & $\$ 27.46$ \\
\hline & Engineering/Technical & 0.85 & 3775 & $\$ 34.06$ \\
\hline & Social Sciences & 0.79 & 2689 & $\$ 23.41$ \\
\hline & Natural Sciences/Math & 0.81 & 1931 & $\$ 27.58$ \\
\hline & Other & 0.81 & 5248 & $\$ 26.39$ \\
\hline \multirow{10}{*}{ Advanced } & Health & 0.88 & 1654 & $\$ 39.07$ \\
\hline & Arts/Humanities & 0.81 & 1108 & $\$ 27.11$ \\
\hline & Education & 0.79 & 3524 & $\$ 25.64$ \\
\hline & Communications & 0.84 & 186 & $\$ 26.20$ \\
\hline & Business & 0.86 & 2257 & $\$ 36.06$ \\
\hline & Engineering/Technical & 0.85 & 1556 & $\$ 39.33$ \\
\hline & Social Sciences & 0.84 & 1222 & $\$ 29.65$ \\
\hline & Natural Sciences/Math & 0.82 & 832 & $\$ 34.33$ \\
\hline & Law & 0.90 & 1242 & $\$ 40.39$ \\
\hline & Other & 0.82 & 2700 & $\$ 31.26$ \\
\hline
\end{tabular}

